\title{
3. LUKOIL: patriotic cosmopolite
}

Vagit Alekperov, the President of LUKOIL, was one of only two heads of the Soviet-era oil companies who managed to retain control of their companies the other being Vladimir Bogdanov, the Director of Surgutneftegas (see the chapter on Surgutneftegas in this book). Yet Alekperov's strategy has been to move with the times and, in many cases, take the lead on forging change in the Russian petroleum sector, unlike Bogdanov, who has sought to resist change as much as possible.

LUKOIL has enjoyed close ties with the Russian authorities and has always sought to maintain a good relationship with the tax collector. The company has been at the forefront of reform in the industry, driving privatization in the 1990s and promoting technological innovation in the 2000s and 2010s, including shale oil extraction. LUKOIL now lobbies for fair opportunities for private firms in offshore development. The company has sought international partnerships and opportunities to establish its upstream and downstream operations abroad while also developing a strong position in the domestic industry. It has responded flexibly to the challenges posed by oil price volatility and sanctions.

LUKOIL seeks to maintain its reputation as a good corporate citizen that engages in various social investment activities in the areas where it operates. In Russia, this is largely via agreements negotiated with local authorities. The company has committed itself to several domestic and international initiatives that require high levels of transparency and reporting to international standards. LUKOIL measures and monitors its climate change impact, promoting APG utilization in its operations, developing new climate change mitigation technologies and supporting renewable energy projects and research.

LUKOIL is Russia's second-largest oil company after Rosneft. It is one of the most internationalized Russian oil companies, operating in over 30 countries, both upstream and downstream. Headquartered in Moscow, LUKOIL is fully privatized, and its most significant shareholders are Vagit Alekperov (25\%), Leonid Fedun (10\%), IFD Kapital (8\%) and LUKOIL Investment Cyprus (9.2\%) (Kommersant 2017a).

Having produced 87 million tonnes of oil in 2018 in total, LUKOIL currently accounts for $12 \%$ of proved reserves, $16 \%$ of crude production and $15 \%$ of refining in Russia. Globally, the company accounts for $1 \%$ of proved oil reserves, $2 \%$ of production and $2 \%$ of refining (LUKOIL 2018a). LUKOIL has four refineries, two mini-refineries and four gas-processing plants in Russia, as 
well as four refining and petrochemical facilities outside the country (LUKOIL 2018b). It also owns 5390 petrol stations in Russia and 18 other countries (LUKOIL 2018c).

\section{CORPORATE HISTORY: LUKOIL REDEFINES THE RUSSIAN PETROLEUM INDUSTRY}

\section{The 1990s}

The state oil enterprise LangepasUraiKogalymneft was established on 25 November 1991 by a decree of the USSR Council of Ministers initiated by the First Deputy Minister of the Oil and Gas Industry, Vagit Alekperov. Alekperov had studied the activities of international oil companies (IOCs), and proposed establishing vertically integrated oil companies in Russia, based on the Soviet oil production associations and using Western majors as a role model. $\mathrm{He}$ wrote in his book Russian Oil that 'in our opinion, we ought to apply the experience of the Western oil companies that unite enterprises throughout the technological chain from well-head to fuel station' (Alekperov 2011, p. 343).

Initially, LangepasUraiKogalymneft included three Siberian production associations (Langepasneftegaz, Uraineftegaz and Kogalymneftegaz) as well as refineries in Perm, Volgograd, Ufa and Mazeikiu. The open joint stock company (OJSC) LUKOIL was created on 5 April 1993 by Government Decree 299 'On Establishment of the OJSC LUKOIL', incorporating the three production associations and just two of the refineries, Perm and Volgograd, along with petroleum product distributors in several Russian regions. Its privatization programme was approved in the same year, and the first issue of shares was registered (LUKOIL 2018j). Under Government Decree 861 of 1 September 1995 'On Improving the Structure of the OJSC LUKOIL', controlling stakes in nine oil production and marketing and service enterprises in the Urals, Volga and Western Siberian regions were added to LUKOIL's authorized capital (LUKOIL 2018k).

During the 1990s, LUKOIL was the undisputed flagship of the Russian oil industry, thanks to the leadership of Vagit Alekperov. The Russian government and Prime Minister Victor Chernomyrdin promoted key LUKOIL initiatives. Yuri Shafranik, the Minister of Fuel and Energy, said at the annual general meeting of LUKOIL in April 1995 that 'LUKOIL projects have always been supported, are currently supported and will be supported in the future by the authorities' (Kommersant 1996).

During the 1990s, LUKOIL drove change in Russia's oil sector. It was the first Russian oil company to develop a privatization plan, and in late 1993, some $12 \%$ of LUKOIL shares were sold at voucher and money auctions. Roughly $8 \%$ of the shares were distributed among its executives and person- 
nel, including Alekperov and LUKOIL's Vice President, Leonid Fedun. The government held $80 \%$ for three years. The next phase of privatization began in October 1995 when bonds were issued to be swapped for ordinary shares. Once the bonds had been redeemed, the government stake was reduced by $11 \%$.

In December 1995, a 5\% state stake was sold at a loans-for-shares auction, and $16.07 \%$ of the shares were offered at an investment tender. LUKOIL bought its own shares at the loans-for-shares auction (Hudson 1996). In this manner, LUKOIL completed consolidation in 1995, ahead of other oil companies. LUKOIL was the first among its counterparts to recruit an international auditor, KPMG, in 1994 (Neftegaz.ru 2000) and, in 1995, became the first Russian oil company to have an international major among its shareholders: Atlantic Richfield Company (ARCO) (see the section on partnerships with foreign companies below).

During the 1990s, LUKOIL acted as Russia's petroleum ambassador. It was the first Russian oil company to enter the other former Soviet republics, starting with Kazakhstan and Azerbaijan, and Boris Yeltsin's government appointed LUKOIL the coordinator of all Caspian petroleum projects. LUKOIL was also the first to expand beyond the countries of the former Soviet Union and has been active in the Middle East since the mid-1990s, including in Egypt and Iraq.

Throughout its history, LUKOIL has followed a basic rule: to spend what it earned on new acquisitions in the oil sector (Khrennikov 2007). Thus, in 1997, LUKOIL gained control over the oil production company Arkhangelskgeoldobycha and, in 1999, became the key player in Timan-Pechora through the acquisition of the holding company KomiTEK (including the oil production company Komineft, an oil refinery and a fuel marketing unit). Having bought KomiTEK, LUKOIL pledged to improve the environmental situation in the Komi Republic, which had deteriorated due to persistent leakage of oil from Komineft pipelines, including a major spill in 1994 (LUKOIL 2016b, p. 59). LUKOIL established the Timan-Pechora petroleum province where it worked with ConocoPhillips after they signed a memorandum of understanding (MoU) for the joint development of the region with the American major in 1998.

Prior to the 2000s, LUKOIL operated as a state within the state: the company owned tankers and railroad cisterns, a drilling company, LUKOIL-Bureniye, as well as a bank and an insurance company. In 1997, LUKOIL was the first Russian company to begin the large-scale construction of fuel stations operating under its own brand name in Russia; it also started purchasing fuel stations abroad (see the section on internationalization below). It also entered the petrochemical sector and bought Russian Stavrolen in 1998 (see Poussenkova 2010). In addition, it became involved in non-core business activities. Thus, in 
1993, the government adopted the Programme of Revival of the Trade Fleet. As an integral element of this programme, LUKOIL launched the construction of new ice-class tankers - a significant contribution to the restoration of manufacturing in Russia. Between 1997 and 2002, it built five Arctic-class tankers in Germany and Saint Petersburg and five river-sea class tankers in Volgograd.

\section{The 2000s}

In the new millennium, LUKOIL continued to pursue the same strategy, although it relinquished its status as Russian oil sector flagship to Rosneft. Vagit Alekperov was quick to discern the implications of the changes in Vladimir Putin's Russia and adjusted his modus operandi accordingly. As Isabel Gorst of the Financial Times noted in 2007, 'until recently, LUKOIL's Western critics often complained that the company was a dinosaur, rooted in the operational and management practices of the past. But LUKOIL is, in fact, highly adaptive, surviving over 15 years of tectonic changes in the Russian oil industry' (Gorst 2007, p. 1).

One of LUKOIL's basic rules was not to quarrel with the tax authorities. In 2002, LUKOIL willingly paid USD 103 million that the revenue service was demanding for the use of the so-called Baikonur scheme of trading petroleum products, which made it possible to evade excises and profit tax. In 2005, LUKOIL settled all tax claims up to 2003. Unlike Mikhail Khodorkovskiy, Vagit Alekperov did not have any political ambitions, which helped him avoid serious confrontations with the authorities.

LUKOIL responded to the new market demands of the time. If LUKOIL had previously been the state within the state, in 2002, the company began to divest itself of its non-core assets. This decision was partly because LUKOIL was about to lose its leadership status in oil production to YUKOS and partly because it needed to cut costs; it also needed to satisfy foreign investors who did not appreciate the concept of non-core businesses in the structure of an oil company.

During the 2000s, LUKOIL had uneasy relationships with its foreign partners, entering into and breaking up several partnerships, including with ARCO, BP (which acquired ARCO in 2000) and ConocoPhillips (see the section on partnerships with foreign companies below).

During the 2000s, LUKOIL strengthened its position in the refining sector by buying NORSI-Oil's near-bankrupt Nizhny Novgorod refinery for USD 26 million. It also developed its export capacities by establishing the Varandei oil terminal on the shore of the Barents Sea in 2008 (see the section on Arctic and offshore projects below).

In the early 2000s, LUKOIL became the first Russian company to gain a foothold in Saudi Arabia through a partnership with Saudi Aramco. It 
strengthened its relationships with the Commonwealth of Independent States (CIS), entering Uzbekistan with a focus on gas production. It also expanded into the foreign downstream, purchasing refineries and fuel stations in Europe, although anti-Russian sentiment made it difficult to achieve a strong position in some countries. Also, LUKOIL became the first and only Russian oil company to establish itself in the United States with a network of fuel stations (see the section on internationalization below).

In 2005, LUKOIL strengthened its position in Kazakhstan by acquiring oil producer Nelson Resources. However, its activities in the early 2000s in Azerbaijan declined somewhat compared to the 1990s. Beyond the CIS, LUKOIL has been active in upstream operations in Latin America since the early 2000s, notably in Colombia and Venezuela. It was one of the first Russian oil companies to begin operations in Africa, including Cote d'Ivoire, Cameroon and Nigeria in the 2000s, mainly working offshore (see the section on internationalization below).

\section{Post-2010}

In 2011, LUKOIL's oil production declined for the first time, by 5\%, and the company called the year 'the bottom', hoping that things would not get any worse. It also had to write off the costs of dry wells amounting to USD 417 million in 2011, almost twice as much as the previous year (Kommersant 2012a). The misfortunes of 2011 sent a strong alert to LUKOIL's leadership that they needed to expand the company's reserve base and gain access to new assets.

In December 2011, LUKOIL deepened its activities in Timan-Pechora through a partnership with Bashneft in the Bashneft-Polyus joint venture (Kommersant 2012b). However, in May 2012, at the request of a minority shareholder of Bashneft, the Russian extractive industry regulator Rosnedra revoked the licence for Trebs and Titov fields from Bashneft-Polyus, returning it to Bashneft (Vedomosti 2012a). It took the partners almost two years to reverse this decision. Oil production at Trebs and Titov began in 2013 and could reach 4.5 million tonnes per annum at its peak. In 2012, LUKOIL won the competition with Rosneft for the Imilorskoye group of fields in Khanty-Mansi Autonomous District. The company hoped that this victory would help it maintain its levels of oil production in Western Siberia, which had declined by $17.5 \%$ over the previous five years (Kommersant 2012c).

LUKOIL currently faces serious exploration and production (E\&P) challenges, given the depletion of its mature fields in Western Siberia - its main region of operations. LUKOIL's oil production in Russia began to decline steadily in 2015, and in Western Siberia it fell in 2009, 2015 and 2016, that is to say, when oil prices were low. This poses an additional problem since main- 
taining oil production volumes in Western Siberia requires the use of costly state-of-the-art technologies.

LUKOIL's prospects in foreign refining improved post-2010 with the purchase of refineries in Italy and the Netherlands in the late 2000s. However, the tax and anti-monopoly authorities in Bulgaria and Romania have brought LUKOIL's refining ventures under close scrutiny. While building up a network of fuel stations in various European countries, anti-Russian sentiments led LUKOIL to divest itself of all its fuel stations in the Baltic States (see the section on internationalization below).

In the 2010s, LUKOIL was winding down its operations in Venezuela and Colombia while entering Mexico at the same time. It continued its engagement in Africa with new activities in Ghana from 2014 onwards; it has also been active in Norway, Romania and Vietnam. In 2016, LUKOIL's gas production increased in both Kazakhstan and Uzbekistan, although it came into conflict with the Kazakh authorities over the Karachaganak project (see the section on internationalization below).

\section{COMPANY PROFILE}

\section{Production Strategy}

LUKOIL's strategic priority is implementing new projects to increase production. This entails both developing greenfield sites and intensifying production at brownfield sites by using advanced technologies, increasing development drilling and enhancing oil recovery (LUKOIL 2018d). LUKOIL's strategy identifies 'growth projects' and 'traditional projects'. The company believes that its top priority should be to ensure increased oil production from growth projects and to stabilize its volumes in its traditional regions of operation.

Growth projects include the Imilorsko-Istochniy licensing area in Khanty-Mansi Autonomous District, Western Siberia, ${ }^{1}$ the Bolshekhetsk depression in Yamal-Nenets Autonomous District in the north of Western Siberia, the Yareg and Usinsk fields in Timan-Pechora as well as the offshore fields in the North Caspian (Filanovskogo, Korchagina and Rakushechnoye) and two Uzbek projects (Kandym-Hauzak-Shady and South-West Gissar). Traditional areas of LUKOIL's activities (Western Siberia, Timan-Pechora, Volga-Urals and Kaliningrad regions) are characterized by well-developed production and social infrastructure with some growth projects.

Appreciating the limitations of LUKOIL's reserve base and production, Vagit Alekperov formulated its E\&P goals as follows: 'We want to find a major exploration project in Russia to create a petroleum province as we did with the Caspian Sea in the past. We are considering territories in Krasnoyarsk Krai, Sakha and the Irkutsk region' (Vedomosti 2013a). In line with this goal, 
in 2016, LUKOIL began 2D seismic testing on the Vostochno-Taimyrksiy plot in Eastern Siberia.

LUKOIL is one of the few vertically integrated oil companies in Russia that has a relatively well-balanced ratio between oil production and refining, and it has always made an effort to develop its refining segment. In 2016, LUKOIL commissioned a complex for the deep refining of vacuum gas-oil (the largest in Russia) at the Volgograd refinery. This complex became the final key facility in the large-scale upgrading that LUKOIL launched in 2008. Thanks to this programme, LUKOIL became the first oil company in Russia to make a full transition to production of Euro-5 motor fuels.

LUKOIL has always emphasized the development of its gas business. In 2018, the company's total commercial gas output was 36 billion cubic metres, indicating significant growth from 20 billion cubic metres in 2016. In Russia, LUKOIL's gas production is based on the fields of Bolshekhetsk depression. Its key producing field there is Nakhodkinskoye, which accounts for some $60 \%$ of LUKOIL's gas output in Russia. Gas is delivered to the Yamburg gas compressor station and is later pumped through Gazprom's pipelines.

In 2018, international projects made a significant contribution to LUKOIL's total gas production: its output increased to 16 billion cubic metres accounting for $47 \%$ of its gas output (see the section on internationalization below).

LUKOIL processes gas at its processing plants in Western Siberia, Timan-Pechora and the Volga regions, and also at its Perm refinery and the Stavrolen petrochemical facility. In 2016, volume of gas processed rose by $6.6 \%$ to 4 billion cubic metres (LUKOIL 2018e). In 2016, LUKOIL commissioned a 2.2-billion-cubic-metre facility at Stavrolen that would enable the processing of North Caspian gas into liquids and commercial gas (LUKOIL 2016a, p. 23).

In the gas business, LUKOIL demonstrates its typical pragmatism by cooperating with Gazprom. The two companies signed a strategic agreement in 2005 under which LUKOIL committed to selling its gas to Gazprom at the well-head. The agreement also envisaged the joint participation of the two companies in the exploration and development of new fields in Russia and Uzbekistan. In 2014, Gazprom and LUKOIL extended their strategic agreement for ten years: LUKOIL would continue selling to Gazprom all the natural gas it produced in Russia, regardless of whether volumes and prices changed. LUKOIL does not want to trade its gas in Russia independently mainly because of difficulties with access to the Unified Gas Supply System.

Unlike Rosneft and Novatek, which have been trying to lure customers away from Gazprom, LUKOIL does not have the lobbying power that they have and prefers to treat Gazprom as an ally rather than as a competitor. However, in February 2017, LUKOIL asked the government for the first time to include 'liberalization of the gas market as well as access to the continental 
shelf' among the state energy policy priorities aimed at increasing competitiveness within the sector.

LUKOIL differs from its counterparts in its focus on petrochemicals. It owns petrochemical facilities in Russia (Saratovorgsyntez, Stavrolen), Bulgaria (Neftokhim Burgas) and Italy (ISAB). LUKOIL meets domestic Russian demand for certain chemical products and exports chemicals to some 30 countries (LUKOIL 2018f). The company has also successfully engaged itself in power generation, particularly in southern European Russia (providing 99\% of power consumed in the Astrakhan region and 62\% in Krasnodar Krai). LUKOIL's power generation business is represented by a whole vertically integrated chain from generation to transmission and sales of heat and electricity to external consumers. The total capacity of LUKOIL's power-generating facilities amounts to $5.8 \mathrm{GW}$ and is made up of $73 \%$ commercial generation and $27 \%$ supporting generation.

\section{LUKOIL's Role in the Arctic and Offshore Oil Extraction}

Since 2008, Russian law has restricted offshore exploration and production licences to experienced state-owned companies (Rosneft and Gazprom). The restriction applies to areas more than 12 nautical miles from the coast, that is to say, beyond territorial waters. LUKOIL was already operating in Russia (the Caspian and Baltic Seas) prior to 2008. It was allowed to keep these projects but has not been able to apply for any new licences (The Barrel 2015).

Vagit Alekperov has long argued for the equal rights of private and state oil companies to carry out offshore projects in Russia. He has complained that the state selects only those 'who have the right' rather than the experience and technologies (Vedomosti 2012b). Arguing for the liberalization of access to the Russian continental shelf, Alekperov said that 'LUKOIL is a Russian national company; it is a taxpayer in Russia; the state authorities control it on equal terms with the state companies. We follow the same laws; we are inspected by the same authorities' (Vedomosti 2013a).

The Russian authorities are now considering opening up offshore reserves to private companies mainly because state-owned companies have found it difficult to meet their licence obligations in an era of low oil prices and Western sanctions. While LUKOIL would welcome reform, the same challenges could also undermine their own ambitions (The Barrel 2015).

Despite the regulatory limitations and practical challenges, LUKOIL is one of the few Russian oil companies that has accumulated a significant amount of experience of offshore operations in both Russia, where it tends to work alone, and abroad, where it is usually part of international consortia (see the section on internationalization below for more on its international projects). 
LUKOIL has been leading operations on the Russian continental shelf for over 20 years. It began large-scale exploration in the Caspian Sea in 1995. Since then, it has discovered ten new fields in the Russian sector of the Caspian Sea, with total recoverable reserves of 1.1 billion tonnes of oil equivalent.

In April 2010, LUKOIL commissioned its first project in the Russian sector of the Caspian Sea - the Yuri Korchagin field (discovered in 2000). This field yielded 1.6 million tonnes of oil in 2015. The Filanovskogo field (discovered in 2005) was commissioned in 2016. This was the largest oil field in the Russian sector of the Caspian Sea, with 80 times the average output of LUKOIL wells, and with recoverable reserves of oil totalling 129 million tonnes and 30 billion cubic metres of gas. Taking into account the environmental vulnerability of the Caspian Sea, LUKOIL aims for zero discharges from the Filanovskogo field and deposes all waste onshore (LUKOIL 2016a, p. 4). LUKOIL's other Caspian fields include Kuvykin and Rakushechnoye, which are due to be commissioned in 2022 and 2026, respectively.

Overall, the Caspian Sea has brought LUKOIL many disappointments in terms of the discovery of commercially viable hydrocarbon reserves, such as the Karabakh project in the Azeri sector, the Tyub-Karagan field in the Kazakh sector (Vedomosti 2008a) and the Yalama field in the Azeri sector (Vedomosti 2009a). Nonetheless, the Caspian Sea remains LUKOIL's most profitable region. Its projects in the Russian sector of the Caspian offer the greatest fiscal benefits (low rates of mineral production tax and zero export duty). Therefore, the Caspian Sea is set to become one of the key sources of LUKOIL's income (Vedomosti 2016a). LUKOIL has hoped to stem the decline of its Russian production through its Caspian projects. Its leadership always reminds the government about its achievements in the Caspian when it tries to convince the authorities to remove constraints on private companies for offshore operations.

LUKOIL is also active in the Baltic Sea. In 1997, it started developing the Kravtsovskoye field, which produced its first commercial oil in 2004. This was the first purely Russian offshore project that entered the commercial phase. In 2015, LUKOIL-Kaliningradmorneft made several small discoveries in the Baltic Sea. In 2016, LUKOIL tried to obtain another plot - Nadezhda - in the Baltic Sea. This is located within the 12 nautical mile zone, that is, in territorial waters; therefore, private oil companies can hope to secure access to the reserves.

LUKOIL has yet to develop offshore operations in Arctic waters. However, much of LUKOIL's production activity in the Timan-Pechora province is located north of the Arctic Circle in Nenets Autonomous District and the northern Komi Republic. Therefore, the company is familiar with working in onshore Arctic locations and has made efforts to develop the related infrastructure. With rising oil production and a lack of essential infrastructure in northern European Russia, LUKOIL built the Varandei oil terminal on the shore of the 
Barents Sea - the world's first 12-million-tonne-per-annum ice-resistant oil pier operating all year round in the Arctic. It is intended for marine transportation of exported oil that LUKOIL produces in Nenets Autonomous District. Launched in 2008, the terminal works on a 'zero-discharge' basis (Alekperov 2011, p. 384).

\section{Partnerships with Foreign Companies}

LUKOIL's first foreign partnership was established in the mid-1990s: in 1995 and 1996, the American company ARCO bought securities worth USD 250 million and became a shareholder of LUKOIL, with $7.99 \%$ of the shares. In 1997, the two companies formed the joint venture LukArco to seek opportunities within and outside Russia. The joint venture was unable to obtain any assets in Russia but acquired 5\% of TengizChevroil in Kazakhstan and 12.5\% of the Caspian Pipeline Consortium.

During the 2000s, LUKOIL had uneasy relations with its foreign partners. Following the acquisition of ARCO in 2000, BP became the owner of $7.99 \%$ of LUKOIL. However, in January 2003, BP sold this stake (LUKOIL 2018g), and in 2009 BP withdrew from the joint venture LukArco because of a disagreement with Caspian Pipeline Consortium partners. LUKOIL bought out its $46 \%$ share for USD 1.6 billion and became the sole proprietor of LukArco (Vedomosti 2009b).

In September 2004, ConocoPhillips bought the 7.59\% stake in LUKOIL (the last stake in the company owned by the state) for USD 1.9 billion and, afterwards, gradually increased its share to $20.86 \%$. The Kremlin was satisfied with the deal, and Alekperov was awarded the Order for Service to the Fatherland of the fourth degree in 2005 (Neftrossii.ru 2014). ConocoPhillips was supposed to help promote LUKOIL's projects in the West. Training of LUKOIL's personnel in ConocoPhillips's offices in Houston was another important aspect of the deal, while 15 leading experts of ConocoPhillips worked as advisors at LUKOIL's headquarters.

In 2005, ConocoPhillips (30\%) and LUKOIL (70\%) established Naryanmarneftegaz to develop the northern part of the Timan-Pechora basin, primarily the large Yuzhno-Khylchuyusk field launched in 2008. It was hoped that this asset would help combat LUKOIL's oil production decline in Western Siberia (Vedomosti 2008b). However, these ambitions were not realized because of a serious error made by the geologists. In 2008, the proved reserves of Yuzhno-Khylchuyusk had been estimated at 70 million tonnes; however, oil production there fell from 7 million tonnes in 2009 to 3.3 million tonnes in 2011, and its reserves were downgraded to 20 million tonnes in 2011 (Kommersant 2012a). 
In March 2010, ConocoPhillips announced that it wanted to sell its stake in LUKOIL. In August, LUKOIL's subsidiary bought $7.59 \%$ for USD 3.44 billion. Leonid Fedun explained the purchase thus: 'We considered it our patriotic duty that these shares should return to Russia' (Vedomosti 2010a). Seemingly the company received a signal from the Kremlin that outside investors should not be allowed to acquire the stake. After that, LUKOIL purchased the remaining shares (Vedomosti 2010b). In 2012, LUKOIL also bought out ConocoPhillips's shares in Naryanmarneftegaz, thus ending its collaboration with ConocoPhillips. Alekperov stated that after ConocoPhillips sold its stake in LUKOIL, LUKOIL's chances of receiving access to reserves would improve because it no longer had a strategic (foreign) partner with $20 \%$ (Neftegaz.ru 2010).

\section{Internationalization}

LUKOIL was the first Russian oil company to internationalize aggressively. It started expanding abroad during the 1990s and continued the trend in the 2000s and 2010s. Flexibility and rationality characterize LUKOIL's globalization policy. Thus, the company has not internationalized just for the sake of internationalization, and it has been disciplined about selling assets that have proved to be commercially unsatisfactory. However, the company's Russian roots have sometimes diminished its options, particularly when it has attempted to enter the European downstream sector, where it continued to be regarded with suspicion as a possible tool of the Kremlin despite being a wholly privately owned company.

The reasons for LUKOIL's globalization were multifaceted: a need to increase its reserve base and supplement declining production in Western Siberia, a desire to get access to offshore projects denied to it in Russia after 2008 and the intention to reduce the fiscal burden. LUKOIL's foreign ventures also allowed the company to learn from its international partners' modern management techniques. Alekperov noted: 'We have consortia with Exxon, Shell, BP and Chevron in many regions of the world. We have adapted to this system of operations when everybody bears his share of responsibility' (Neft Rossii 2016).

In the 1990s, LUKOIL began work at the Tengiz and Kumkol fields in Kazakhstan. In 1993, it signed its first framework agreement with SOCAR - the state oil company of Azerbaijan. In 1994, the so-called contract of the century was concluded for Azerbaijan's Azeri-Chirag-Guneshli fields in which LUKOIL held 10\% (Newsru.com 2002). LUKOIL subsequently expanded to other fields in Azerbaijan: Shakh-Deniz, Yalama and Karabakh. At the time, it was vitally important for Russia to re-establish its influence in the post-Soviet space and restart energy dialogues with CIS countries, 
and LUKOIL played a key role in steering Russia's foreign policy towards Azerbaijan and Kazakhstan (Gorst and Poussenkova 1998). In the early 2000s, LUKOIL continued its strategy of strengthening its position in the former Soviet republics, entering the upstream of Uzbekistan, which became an important part of LUKOIL's gas business.

The Middle East is another strategic region for LUKOIL, with operations in Saudi Arabia, Iraq and Egypt. The Meleiya project in Egypt, which LUKOIL joined in 1995, was one of its first overseas E\&P ventures and continues to be productive. Currently, LUKOIL is involved in this project and in two other projects in Egypt. Iraq was also a focus of LUKOIL's globalization efforts from the start. In 1997, LUKOIL bought a controlling interest in the Russian consortium established to operate the West Kurna-2 deposit in Iraq. It also formed the joint venture LukAgip with the Italian Agip to develop petroleum fields in Tunisia, Egypt and Libya (in 2005, LUKOIL bought Agip out of the joint venture). In a significant development, LUKOIL was the first Russian company to gain a foothold in Saudi Arabia with the LUKSAR joint venture, which was established in 2004 between LUKOIL (80\%) and Saudi Aramco $(20 \%)$.

What was unusual at the time was that LUKOIL entered the foreign downstream sector. Taking advantage of the global economic downturn after the 1998 financial crisis, LUKOIL bought refineries in Bulgaria, Romania and Ukraine at knock-down prices. LUKOIL Neftokhim Burgas, the only refinery in Bulgaria, accounts for some $70 \%$ of wholesale deliveries of fuel in the country. LUKOIL, with its over 200 petrol stations in Bulgaria, controls roughly $26 \%$ of the market.

\section{Table 3.1 LUKOIL's fuel retail acquisitions in Europe}

\begin{tabular}{|c|c|c|c|}
\hline Year & Country & LUKOIL acquisitions & $\begin{array}{l}\text { Number of } \\
\text { stations }\end{array}$ \\
\hline 2003 & Serbia & $79.5 \%$ share in Serbia's Beopetrol for EUR 117 million & 200 \\
\hline 2005 & Finland & Oy Teboil Ab and Suomen Petrooli Oy for USD 160 million & 289 \\
\hline 2006 & Hungary & $\begin{array}{l}15 \text { petrol stations in Hungary from Austria's ABA, bringing the } \\
\text { number of its fuel stations in Hungary to } 26 \text { units }\end{array}$ & 26 \\
\hline 2006 & $\begin{array}{l}\text { South-Eastern } \\
\text { Europe }\end{array}$ & $\begin{array}{l}\text { Joint venture with Slovenian Petrol ( } 51 \% \text { ) to deal with retail sales } \\
\text { of petroleum products in South-Eastern Europe (Vedomosti 2006a) }\end{array}$ & \\
\hline 2007 & $\begin{array}{l}\text { Six European } \\
\text { countries }\end{array}$ & $\begin{array}{l}\text { Petrol stations in six European countries from ConocoPhillips for } \\
\text { USD } 442 \text { million }\end{array}$ & 376 \\
\hline 2012 & $\begin{array}{l}\text { Belgium/ } \\
\text { Netherlands }\end{array}$ & $\begin{array}{l}\text { LUKOIL's Zeeland refinery (formerly TRN) supplies fuel to its } \\
\text { petrol stations in Belgium and the Netherlands (Vedomosti 2012c). }\end{array}$ & $13+46$ \\
\hline
\end{tabular}

Source: LUKOIL website. 
LUKOIL was the first and only Russian oil company to gain a foothold in the United States. It did so with the acquisition of Getty Petroleum Marketing, with 1300 fuel stations in 2000, and the purchase of a network of 795 Mobil-branded fuel stations in New Jersey and Pennsylvania from ConocoPhillips. By mid-2005, LUKOIL controlled $8 \%$ of the retail fuel market in these regions (Vedomosti 2005a). However, in December 2007, LUKOIL began ridding itself of the Mobil fuel stations (Energyland 2008), and in early 2011 it sold Getty Petroleum. As a result, its number of US fuel stations fell from 1334 to 635 in 2011 (Vedomosti 2011) and 285 in 2016.

During the 2000s, LUKOIL failed to obtain any refining facilities in Europe, which forced it to focus on developing its Russian refining assets (Neftegaz. ru 2007). In 2002-03, the Greek government blocked LUKOIL's attempt to negotiate a $23 \%$ stake in the Greek state company Hellenic Petroleum with its three oil refineries and 1500 fuel stations. The trade unions had strongly opposed the proposal, and the government deemed it 'unacceptable from the point of view of national interests' (Gaiduk and Lukin 2006). In 2002, LUKOIL's attempts to purchase Polish refineries and gas stations failed for political reasons (Neft i kapital 2002). LUKOIL was also unable to acquire Mazeikiu Nafta in Lithuania. In 2006, LUKOIL reached an agreement with Kuwait Petroleum International to buy a refinery in Rotterdam; however, its owners changed their mind at the last moment (Energetika i Promyshlennost Rossii 2008). In 2007, LUKOIL wanted to acquire a share in the Czech refinery Ceska Rafinerska from ConocoPhillips; however, the Czech government was unwilling to see a Russian company among the shareholders and preferred to work with ENI. In 2008, LUKOIL's attempt to purchase a 30\% stake in Spanish Repsol was approved by the Spanish Prime Minister; however, the opposition parties and the media launched a campaign warning that LUKOIL would act as an 'arm of the Kremlin' and hinting about connections with the Russian mafia. Ultimately, LUKOIL had to abandon its plans (Forbes 2009).

In mid-2008, LUKOIL finally made a breakthrough into west European refining. It established a joint venture with the Italian company ERG, to which ERG contributed its 16-million-tonne-per-annum ISAB refining complex in Sicily. LUKOIL purchased $49 \%$ of the shares of the two refineries in the complex, allowing it to double its European refining capacity (Vedomosti 2008c). The deal was closed in December 2008 despite the financial crisis. In 2009, LUKOIL bought $45 \%$ of the Total Refinery Netherlands (TRN) from Total (Vedomosti 2009c). These two acquisitions helped LUKOIL improve the balance between its production and refining volumes. In 2013, LUKOIL bought another $20 \%$ of ISAB for some EUR 400 million; it planned to refine Iraqi oil, primarily from West Kurna-2 (Vedomosti 2013b).

LUKOIL also had trouble with the refineries it had bought in the 1990s, mainly because of the general anti-Russian sentiment in Eastern Europe. 
In 2011, in Bulgaria, LUKOIL was suspected of fraudulent export because LUKOIL's Neftochim Burgas refinery did not install fuel metering devices on time. As a result, officials closed storage facilities in Burgas and revoked the licence of Neftochim Burgas (Kommersant 2011a). LUKOIL managed to settle the problem in court, but almost immediately, the Bulgarian authorities began to accuse the company of violating anti-monopoly legislation and launched investigations of LUKOIL and its trading division. In 2014, the Romanian authorities investigated LUKOIL's Petrotel refinery accusing the company of tax evasion and money laundering, although the charges were dropped in 2016 (Kommersant 2017b).

Table 3.2 LUKOIL's network of petrol stations (number of stations at year-end)

\begin{tabular}{llllll}
\hline & 2012 & 2013 & 2014 & 2015 & 2016 \\
\hline Russia & 2368 & 2424 & 2481 & 2544 & 2603 \\
Western Europe & 2420 & 2427 & 2322 & 2336 & 2177 \\
Baltic States & 212 & 210 & 211 & 142 & 0 \\
CIS & 503 & 479 & 469 & 245 & 244 \\
United States & 425 & 327 & 299 & 289 & 285 \\
\hline
\end{tabular}

Source: LUKOIL (2018j).

LUKOIL's foray into the European fuel retail market was successful because, unlike refineries, the fuel stations were not considered strategic enterprises. In 2003, the company purchased 200 fuel stations in Serbia, followed by 289 units in Finland in 2005 and afterwards in Hungary, Slovenia and other European countries in the mid-2000s. In 2012, the company made further acquisitions in Belgium and the Netherlands (Table 3.1). At the same time, in 2012, LUKOIL decided to sell 85 fuel stations in Serbia because of their low profitability (Kommersant 2012d). In December 2015, Vagit Alekperov admitted that LUKOIL wanted to withdraw from the Baltic States because of strong anti-Russian sentiments there (Vedomosti 2016b); in 2016, the company divested itself of all its fuel stations in the region (Table 3.2).

In 2005 , LUKOIL also strengthened its position in Kazakhstan by acquiring $65 \%$ of the oil-producing company Nelson Resources for USD 2 billion (Vedomosti 2005b). In October 2005, Vagit Alekperov met Nursultan Nazarbayev, who announced that the Kazakh leadership had approved of LUKOIL's activities in Kazakhstan in general and of its acquisition of Nelson Resources in particular (Vedomosti 2005c). However, LUKOIL encountered serious problems with CNPC in Kazakhstan about Turgai Petroleum and its 
acquisition of Nelson Resources; the two companies were forced to settle their differences by arbitration (Vedomosti 2010c). In 2006, Vagit Alekperov commented that LUKOIL is one of the major players in Kazakhstan, where it produces some 6 million tonnes and participates in six big projects.

But one has to note that the Chinese have more opportunities than we do. For example, we could not offer PetroKazakhstan the price that CNPC paid for the company. It is difficult for us to compete with them because we work under market conditions while the Chinese national company has access to cheap and stable government money. (Vedomosti 2006b)

Despite LUKOIL's generally amicable relations with the Kazakh government, it had problems with Karachaganak, as did other consortium members. In April 2016, the Kazakh authorities demanded USD 1.6 billion from the consortium for violating the provisions of its production-sharing agreement (PSA). Similar demands made in 2010, when the consortium was accused of tax evasion and oil production above established levels, had resulted in the transfer of a $10 \%$ stake in Karachaganak to Kazakhstan.

LUKOIL's projects in Central Asia helped it develop its gas business. In 2016, due to the successful implementation of South-West Gissar and Kandym-Hauzak-Shady projects, LUKOIL's gas production in Uzbekistan rose by $8 \%$. LUKOIL's gas production also increased in Kazakhstan by $8 \%$ at the Tengiz field and by $16 \%$ at the Karachaganak field.

Compared to the $1990 \mathrm{~s}$, the 2000 s witnessed the relative weakening of LUKOIL's position in Azerbaijan. In 2003, it sold its stake in the Azeri-Chirag-Guneshli project to the Japanese company INPEX Southwest Caspian Sea for USD 1.3 billion. Alekperov explained that this decision was part of LUKOIL's restructuring programme and announced that the company 'would continue to consider opportunities to withdraw from the projects where it does not have operatorship' (Ria Novosti 2002). Currently, it works mainly on the Shah-Deniz gas condensate field located in the Azeri sector of the Caspian Sea.

LUKOIL has been active in upstream operations in Latin America since the early 2000s. Recently, it decided to wind down its operations in Colombia and Venezuela while entering Mexico at the same time (see Table 3.3).

LUKOIL was one of the first Russian oil companies to begin operations in Africa, entering Cote d'Ivoire in 2006, followed by Cameroon (2008), Nigeria (2009) and Ghana (2014). In these countries, LUKOIL has mainly worked offshore - the area that has been largely denied to it in Russia. Vagit Alekperov said that LUKOIL made a bet on Africa as a promising petroleum region (Kommersant 2012e). The company was particularly active in Africa in 2014, discovering seven hydrocarbon fields in one block in Ghana while also 
joining projects in Cameroon and Nigeria. LUKOIL believes that deep-water projects in West Africa can be very promising but only with higher oil prices. Therefore, the company has decided to adopt a 'wait-and-see' policy on offshore projects, such as Tano in Ghana, OML-140 in Nigeria and Etinde in Cameroon (Kommersant 2017c).

LUKOIL's only activities in Asia are currently in Vietnam where, in 2011, LUKOIL Overseas bought a 50\% stake in an offshore block. As far as European upstream is concerned, LUKOIL is active in Norway where, in 2013, it was one of the winners of the 22nd licensing round. A minor gas field was discovered in 2015 (Kommersant 2013a), but because of its size, by 2016, LUKOIL was contemplating withdrawing from the block as it was dissatisfied with the economics of the project (Kommersant 2016a). LUKOIL entered Romania's upstream in 2011 and managed to discover considerable reserves within the Trident block where it continued exploratory drilling.

\section{Transparency}

In 2011, Transparency International and Revenue Watch released a review of the policies of 44 companies responsible for $60 \%$ of the world's oil production (Transparency International 2011). From Russia, only LUKOIL, Rosneft and Gazprom were present. The report covered three key areas. The first was 'Reporting on anti-corruption programmes', where LUKOIL scored poorly with $9 \%$, ranking below Rosneft (41\%) but above Gazprom (0\%). Second, under 'Organisational disclosure', LUKOIL scored a respectable $50 \%$, although ranking below both Rosneft (75\%) and Gazprom (81\%). The third area was 'country-level disclosure of foreign operations', where most participating countries scored poorly (average 16\%), rendering LUKOIL's $15 \%$ a near-average score (Rosneft and Gazprom did not feature prominently on the list).

In the 2011 report from Transparency International and Revenue Watch, LUKOIL was also identified as a non-supporter of the Extractive Industries Transparency Initiative (EITI), which was perceived as an indication of a company's transparency credentials. To date, neither LUKOIL nor any other Russian company has been listed as a supporter of EITI. The Russian government has not signed up to EITI; however, some of the countries where LUKOIL has its operations have done so (EITI 2018a, 2018b).

Nonetheless, LUKOIL has over the years displayed a growing tendency towards greater transparency and readiness to participate in international initiatives with reporting and disclosure requirements. In 2002, for instance, LUKOIL was the first Russian company to receive a full listing on the London Stock Exchange, which has substantial disclosure requirements (London Stock Exchange 2018). The company is also listed on the Frankfurt, Munich and 
Stuttgart stock exchanges and on the US OTC market. In a 2010 interview with EURACTIV, Alekperov stated that 'LUKOIL is a private company quoted on the London Stock Exchange, and our Western partners see us as any other company working under the principle of transparency in business affairs' (EURACTIV 2018).

LUKOIL produced its first sustainability report in 2005. The sustainability report is now published annually in line with GRI guidelines (GRI 2018) (see the section on CSR below). In 2008, LUKOIL became a member of the UN Global Compact, which requires the participating companies to submit an annual 'Communication on Progress', which is published on the Global Compact website (United Nations Global Compact 2019). Since the start of its reporting in 2009, LUKOIL has progressed from 'Learner' level to 'Active' level in its progress communications (on a par with BP). The highest level is 'Advanced', achieved by Equinor and Shell, among others. Since 2013, LUKOIL has been participating in the Carbon Disclosure Project, which involves disclosing information on its GHG emissions (see the section on climate policy below).

In 2014, WWF Russia and CREON Energy released a rating of the environmental performance of Russian oil and gas companies, including performance on disclosure and transparency. The rating was subsequently updated in 2016, 2017, 2018 and 2019. In 2014, LUKOIL came ninth behind Rosneft (seventh) and Gazprom (third) (Surgutneftegas was ranked the highest). In 2016, LUKOIL came fourth and, by 2017, had worked its way up to second place behind Rosneft but one place ahead of Surgutneftegas, while Gazprom had fallen to sixth place. In the area concerning 'Disclosure and transparency', LUKOIL came in joint eleventh in 2014 and joint third in 2016 but fell to joint sixth in 2017. In 2018 and 2019, LUKOIL achieved first place.

These ratings suggest that LUKOIL has managed to improve its transparency and disclosure. The company appears to have been successful in making steady progress in these areas, although observers have identified room for further improvement.

\section{CSR}

LUKOIL strives to project the image of a good corporate citizen. The company established a charity fund in 1993 - one of the first of its kind in contemporary Russia (LUKOIL 2018h). It is a member of the Global Compact in Russia (see United Nations Global Compact 2019) and is a signatory to the Social Charter of Russian Business (Russian Union of Industrialists and Entrepreneurs 2019). LUKOIL has adopted a unique corporate social code, which, among other things, determines its policy on local communities living nearby its operation sites (LUKOIL 2019a). LUKOIL holds the ISO 14001 standard 
for environmental management systems. It has established a Health, Safety and Environment Committee, accountable directly to LUKOIL's president (LUKOIL 2016b). LUKOIL has also committed itself to support the UN's 2030 agenda for sustainable development (LUKOIL 2016b), and LUKOIL's Sustainability Report 2017 was produced in line with the 2030 agenda goals (LUKOIL 2017).

LUKOIL's sustainability report is now published annually in line with the GRI guidelines (see Global Reporting 2019). In 2017, LUKOIL won the Moscow Exchange Award for the 'Best Corporate Social Responsibility and Sustainability Report'. The company has repeatedly been ranked among the top ten companies in Russia for 'Responsibility and Openness' by the Russian Union of Industrialists and Entrepreneurs, which produces sustainability indexes based on the publicly available reports of Russia's 100 largest companies.

Alekperov's statements at the beginning of LUKOIL's sustainability reports reflect the evolution of LUKOIL's thinking about CSR. Alekperov's address at the beginning of the 2011-12 report focused primarily on LUKOIL's commercial achievements and technical innovations: 'We consider it our duty to pay our taxes in a timely manner, which helps the state to resolve social challenges in the regions of our Company's presence' (LUKOIL 2012, p. 2). Subsequent addresses exhibit a progressively greater focus on the environment and local communities. The 2016 address emphasized the need to balance economic, environmental and social factors in business development. And in the opening paragraph of his 2017 address, Alekperov stated: 'The company has always sought to work not only to benefit its shareholders and employees but also the society as a whole. We are convinced that our successful development is only possible if we take into account the interests of the communities of the countries where we operate' (LUKOIL 2017, p. 6). This indicates a gradual shift, at least in LUKOIL's public relations department, towards appreciating the need to be more explicit in its public announcements on environmental protection and the well-being of local communities and wider society; the company also acknowledges that its responsibility in this sphere transcends the mere need to pay taxes so that the state can take care of things.

According to the Sustainability Report 2016, LUKOIL contributed over RUB 12 billion to charity, sponsorship and social investments (LUKOIL 2016b). The bulk of these funds (RUB 7.3 billion) was channelled via socio-economic partnership agreements with the regions of operations, while RUB 1.8 billion was spent on supporting public funds and organizations. In 2016, LUKOIL signed cooperation agreements with all the Russian regions where it had operations, pledging funds to finance social and sports programmes, construction and maintenance of cultural facilities. In 2018, 
LUKOIL provided social support worth around RUB 9 billion in the regions where it operated (LUKOIL 20181).

LUKOIL's social code sets out how it should interact with indigenous peoples. The provisions are implemented through annually approved programmes in its regions of operation where indigenous peoples live, namely Khanty-Mansi Autonomous District, Yamal-Nenets Autonomous District, Nenets Autonomous District, Komi Republic and Krasnoyarsk Krai. LUKOIL's support for indigenous peoples is provided primarily through agreements between LUKOIL and regional authorities, licensing agreements and agreements on the socio-economic development of the regions where indigenous peoples live. One of the most efficient forms of support is economic contracts on cooperation with heads of the territories inhabited by indigenous peoples. These agreements define the procedure for the use of land, compensation, educational support and medical services. Support provided via such agreements in Khanty-Mansi Autonomous District, for instance, includes cash payments, boats, snowmobiles, boat engines and generators. LUKOIL also signs agreements on cooperation with civil society organizations that represent the interests of indigenous peoples.

LUKOIL coordinates its schedules for field development and exploration activities with indigenous peoples at the planning phase to avoid future conflicts. However, despite the availability of officially formulated policies on local inhabitants, conflicts do occur. For instance, in 2014, a controversy broke out in the Izhma District of the Komi Republic when the citizens unanimously voted for the termination of LUKOIL-Komi's activities in the region, among other things because the company had begun drilling near the village Krasnobor without having notified the local citizens and administration and obtained the requisite permits (Greenpeace 2014). The local population had previously been affected by repeated spills from the ageing oil pipelines in the region, which had undermined LUKOIL-Komi's social licence to operate (Kelman et al. 2016).

LUKOIL tries to regulate the behaviour of the employees of its subsidiaries to avoid conflicts with indigenous peoples. LUKOIL Western Siberia is governed by Order 262 On Measures to Limit Access to Territories of Communal Lands. Departments for interaction with indigenous peoples are established in subsidiaries so that they can convey their complaints and proposals to the company (LUKOIL 2016b, pp. 92-3).

Support for education is another component of LUKOIL's CSR activities. The company has been sponsoring scholarships for talented students specializing in petroleum, petrochemicals and power generation. For instance, in 2016, 185 students across Russia received LUKOIL corporate scholarships. In 2018, 190 students and 79 teachers received scholarships with a total value of RUB 9 million (LUKOIL 20181). LUKOIL also sponsors several specialized 
medical research and development centres and contributes to the development of the system of medical services in the regions of its operations. In 2016, it assisted the Russian Cardiological Scientific Centre, Institute of Surgery, Mezensk Central Regional Hospital, Limansk Regional Hospital, Ukhta Children's Hospital, Perm Children's Clinical Hospital and so on (LUKOIL 2016a, p. 77). The company supports the arts, cultural and historical heritage, religious traditions and spiritual culture, cultural activities, museums, churches and monasteries across the country. Since 2002, LUKOIL has been organizing annual competitions to sponsor social and cultural projects. In 2018, 3645 applications were submitted and 773 projects were financed, and financial support was RUB 141 million (LUKOIL 20181).

In 2006, Vagit Alekperov established the foundation Our Future to provide support for social entrepreneurship. The foundation helps people create new businesses and holds biannual contests for business ventures throughout Russia (Neftegaz.ru 2010). In 2013, Alekperov organized the first international conference, Social Innovations, in which some 400 people participated. The objective was to create an expert forum where people interested in social entrepreneurship could communicate, promote new ideas and identify the problems (Vedomosti 2013c). 'More than a purchase!' is a partner project of LUKOIL and Our Future and involves shops at LUKOIL fuel stations selling goods manufactured by social entrepreneurs. The first outlet opened in 2014 (LUKOIL 2016b, pp. 88-9).

\section{Innovation}

LUKOIL is now more active than ever in applying modern methods of enhanced oil recovery, including hydraulic fracturing (fracking), chemical, hydrodynamic and thermal methods. In 2016, 237 horizontal wells were completed with an average daily output of 79 tonnes per day, including 87 wells with multi-zone fracking. The share of the horizontal wells grew from $22 \%$ in 2015 to $28.6 \%$ in 2016 (LUKOIL 2016a, p. 53).

LUKOIL has sought partnerships with foreign companies to help develop and apply new technologies, an example of which is its partnership with Total to exploit shale oil reserves in Western Siberia. However, the partnership was halted because of the international sanctions against Russia in connection with the conflict in Ukraine (see the section on the shale revolution below). LUKOIL has also become involved in hard-to-recover reserves overseas to gain experience. For instance, in partnership with Saudi Aramco, LUKOIL carried out an appraisal of tight gas production techniques for the Tuchman and Mushaib fields (Reuters 2014). 


\section{COPING WITH CHANGE}

\section{Shale Revolution}

Thanks to the Bazhenov formation in Western Siberia, Russia has the second-largest shale oil reserves in the world (after the United States). LUKOIL has long been trying to develop the Bazhenov formation. In its Sustainability Report 2011-2012 (p. 12), the company stated that the currently available technologies will only be sufficient to recover $2-4 \%$ of the Bazhenov reserves. It has, therefore, invested in the development and testing of advanced technology through its subsidiary RITEK (Russian Innovative Fuel and Energy Company). RITEK is already active in developing advanced methods for extracting oil from the Bazhenov formation, including a system of the thermo-gas impact that is aimed at heating the surrounding rock (Alekperov 2011, pp. 387-8). RITEK applied the technology of thermo-gas impact at test sites for the first time in 2009, hoping that this technology would permit increasing the oil recovery ratio by $10-30 \%$ (Oilgas.com 2017). The second test site was commissioned in 2015. In 2017, RITEK drilled one well at a third testing site (Neftegaz.ru 2017).

LUKOIL has sought foreign partners with relevant skills and state-of-the-art technologies to work on the Bazhenov formation. In 2014, LUKOIL (51\%) and Total (49\%) signed an agreement creating a joint venture to explore and develop the tight oil potential of Bazhenov (Vestifinance.ru 2014). The partners planned to begin seismic testing in 2014 and exploration drilling in 2015. However, the activities were halted because of the anti-Russian sanctions that targeted the development of shale reserves. Total hoped that they could return to the project as soon as the sanctions were lifted. Without a foreign partner, LUKOIL would likely be able to begin only test production at the Bazhenov formation. Alekperov said that LUKOIL appreciated the difficulties that Total faced and that 'we undertook this mission, and we'll finance this programme' and that the French major could return to the project compensating for LUKOIL's costs incurred during its absence (TASS 2015).

\section{Oil Price Volatility}

LUKOIL, and Vagit Alekperov in particular, have always monitored global oil prices closely. The company has made efforts to forecast them and has developed its budgets proceeding from realistic and sometimes even conservative scenarios. It is noteworthy that LUKOIL produces an energy market outlook on a regular basis called 'Main Trends in the World Oil Market Development up to 2030’ (LUKOIL 2018i). 
Vagit Alekperov has realistic views about economic upheavals, as his following opinion about the 1998 crisis shows:

nevertheless, it was the market system of management that made it possible for the oil sector to survive the crisis. [The year] 1998 was the acid test for the industry when world oil prices dropped to USD 9 per barrel. In this situation, not only did the Russian companies not reduce production, but they did not even freeze their investment programmes. Moreover, the oil price collapse became a driver for the rapid growth of production and financial indicators. It forced the oil companies to drastically improve the efficiency of their activities through cost-cutting, expanding sales volumes and enhancing product quality. (Alekperov 2011, p. 347)

According to Alekperov, the 2008-09 financial crisis allowed LUKOIL to analyse all its mistakes and make unconventional decisions in order to secure the company's long-term stability. This was achieved through cost-cutting and by terminating certain investment projects. Thus, LUKOIL cut its overall costs by $36 \%$, operating costs by $15 \%$ and commercial and administrative costs by $15 \%$. It also reduced investments by almost $40 \%$ (Vedomosti $2009 \mathrm{~d}$ ). In the autumn of 2008, when Russian companies began downsizing on a large scale, Vagit Alekperov assured his employees that 'he would not allow it'. Yet during the first half of 2009, the number of LUKOIL's personnel declined from 152500 to 145600 , although staff were only dismissed from the subsidiaries. The headcount in the head office even increased from 2109 people in 2008 to 2196 in 2009, and their salaries grew (Oilcareer.ru 2009).

Vagit Alekperov made the following statement on the 2008-09 crisis:

The system should be flexible. We were able to weather the period when oil prices dropped from USD 110 to USD 30 per barrel. We cut our investment programme in the areas where it did not directly affect our workers and development prospects. We adapted quickly and did not drastically decrease oil production. We did these things fairly smoothly and flexibly. I hope we will continue to do so in the future. This permits us to maintain our production volume at 110-120 million tonnes per annum. (Neft Rossii 2016)

Alekperov has always had strong (and sometimes wrong) opinions about future oil prices. For example, in a 2006 interview with the newspaper Vedomosti, when asked about his forecast of world oil prices, Alekperov remarked:

In general, the market now is saturated, and oil, production and consumption are balanced. Therefore, as long as there are no political, climatic, or technogenic cataclysms, a major rise of the oil price is not anticipated. Its decline is possible, but it also would not be significant because consumption in China and India is increasing at really impressive rates. (Vedomosti 2006b) 
During the 2009 crisis, Alekperov said that there were no fundamental reasons for oil prices to be below USD 40 and above USD 70 (Alekperov 2009). At the time, he was confident that oil prices would continue to grow. Calculating investments for 2009, LUKOIL proceeded from three scenarios: optimistic (USD 80 per barrel), acceptable (USD 65) and pessimistic (USD 45). LUKOIL's investment programme of USD 7.3 billion was based on a price range of USD 45-50 per barrel (Vedomosti 2009e).

In 2009, Alekperov was convinced that the oil price would continue to increase and would not drop below USD 40. By contrast, in 2010, Leonid Fedun expressed his view that the energy market was on the brink of a revolution due to shale gas production in the United States and rising oil production in Iraq, and that oil prices would never be high again.

LUKOIL's 2030 market forecast contains several scenarios, two of which are titled Concord and Volatility, and LUKOIL analysts believe that 'the average level of oil prices up to 2030 will be close to the level of USD 80 per barrel in constant prices' (LUKOIL 2018i).

\section{Sanctions}

LUKOIL was mainly affected by the sectoral sanctions targeting the Arctic, shale and deep-water oil (the company was not subject to the financial sanctions). As mentioned, it had to freeze its joint venture with Total on the development of the Bazhenov shale formation. Its deep-water projects in the Caspian Sea were also affected. TsentrCaspneftegaz, a joint venture between Gazprom and LUKOIL and the licence holder for Tsentralnaya deep-water structure in the Russian sector of the Caspian Sea, had to postpone drilling until sanctions were lifted. The joint venture could not obtain a drilling rig from foreign companies; therefore, the partners decided to suspend the project for the time being (TASS 2015).

In the context of sanctions, LUKOIL began to think about selling its oil-trading entity Litasco, established in 2000 in Switzerland, because of high maintenance costs. Vagit Alekperov stated that 'I would not say that it is connected with the sanctions, although it is quite difficult for our company to raise external financing while trading transactions require huge turnover capital' (Kommersant 2017d).

LUKOIL was the first Russian oil company to discern the danger of the 2017 US sanctions for foreign assets held by Russian oil companies. Leonid Fedun admitted that LUKOIL was interested in overseas projects; however, the threat of new American sanctions held back the company's acquisitions. 'Now there is a potential threat connected with the new package of sanctions adopted by the United States that limit the possibilities of Russian oil compa- 
nies to own more than $33 \%$ in the project. This constrains us very strongly in several acquisitions' (Kommersant 2017e).

In 2017, a Sberbank CIB analyst summed up LUKOIL's stance on the political and economic situation very clearly: 'the management [of LUKOIL] sobered up when sanctions were placed on Russia, which coincided with the drop in the oil price' (Sberbank CIB 2017, p. 27).

\section{Climate Policy and Changing Demand for Fossil Fuels}

LUKOIL appears to take climate change seriously. Since 2013, the company has participated in the international Carbon Disclosure Project, which requires companies to provide information on their GHG emissions. In 2016 and 2018, based on its results, LUKOIL was awarded a climate score of D (with A being the highest and $\mathrm{F}$ the lowest).

By comparison, BP, ENI, Statoil (now Equinor) and Total all achieved A- (A minus). However, most participating Russian oil and gas companies achieved a score of F, except for Gazprom, LUKOIL and Novatek, which achieved C, D and D- respectively. Since 2015, LUKOIL has been estimating direct GHG emissions of its subsidiaries using the methodology of the Russian Ministry of Natural Resources (LUKOIL 2016b, p. 67). In 2015-16, LUKOIL worked on developing a corporate system for measuring and managing GHG emissions. The total volume of LUKOIL's direct GHG emissions in Russia amounted to 31 million tonnes of $\mathrm{CO}_{2}$ equivalent (LUKOIL 2016b, p. 49).

One of LUKOIL's measures to reduce the climate impact of its activities is increased utilization of APG. It was one of the first Russian oil companies to start reducing gas flaring, even before the state required this. LUKOIL approved the Programme of Rational Utilization of APG by Organizations of the LUKOIL Group for 2016-18.

In 2016, LUKOIL built and upgraded 42 facilities for the utilization of APG. The main efforts were concentrated in Timan-Pechora and the North Caspian. The greatest increment of APG utilization was achieved in Timan-Pechora, where the volume of utilization increased by 267 million cubic metres (16\%) from its 2015 level. However, in the North Caspian, due to the commissioning of the Filanovskogo field and gas production growth, APG utilization declined. In 2016, LUKOIL achieved an APG utilization level of $92 \%$ across the company and $97 \%$ in Western Siberia (LUKOIL 2016 b, p. 23). It aimed to achieve 95\% APG utilization in its Russian subsidiaries by 2018 (LUKOIL 2016b, p. 47). It is noteworthy that the company exceeded this target: in 2018, its level of APG utilization in Russia reached 97.4\% (LUKOIL 2019b). 
In addition, LUKOIL is, in effect, the only vertically integrated oil company in Russia that has shown an interest in renewables. It is noteworthy that its 2030 energy outlook states that 'oil and renewables are not antagonists' (LUKOIL 2018i). In 2016, LUKOIL had four hydropower stations in Russia with a total capacity of $296 \mathrm{MW}$ and an output of 756 million $\mathrm{kW} / \mathrm{h}$. Its total capacity of renewable energy sources, including hydropower, was $390 \mathrm{MW}$ in 2016. LUKOIL first ventured beyond hydropower with pilot projects in 2009 to equip three fuel stations in Serbia and Russia with photovoltaic panels. A renewable energy competence centre to serve LUKOIL units was established based on LUKOIL-Ecoenergo (LUKOIL 2016b, p. 20).

In the 2010s, LUKOIL focused its attention on wind power. In 2013, its 50:50 joint venture with the Italian company ERG, Lukerg Renew, bought four Bulgarian companies that specialized in wind power generation (Globo Energy, Mark 1, Mark 2 and UP Bulgaria 4). Lukerg was established by LUKOIL and Erg SpA in 2011 to jointly invest in renewables in Bulgaria and Romania. The joint venture owns a $40 \mathrm{MW}$ wind farm in Bulgaria and a 84 MW wind power station in Romania (Kommersant 2013b). LUKOIL also has two solar power stations at its refineries in Romania with a total capacity of $9 \mathrm{MW}$ and in Bulgaria with a capacity of 1.3 MW. These stations supply electricity to local networks.

Vagit Alekperov made the following observation:

We have both traditional and solar power generation in Romania and Bulgaria. We entered this segment in Europe to gain experience. Also, because the EU governments promote these projects, they are quite profitable. We wanted to apply our experience in Russia. We decided to install solar modules in the Volgograd refinery, where we launched a 12-MW project. (Neft Rossii 2016)

Vagit Alekperov also recently founded a chair of renewable energy in the Gubkin Oil and Gas Academy led by one of LUKOIL's senior managers.

\section{CONCLUSION}

LUKOIL, the vanguard of change in the Russian oil sector during the 1990s, demonstrated considerable flexibility in adapting to internal changes in Russia during the 2000s and 2010s and swiftly adjusting its strategies. It also demonstrated considerable awareness of external changes, such as low oil prices, climate change and the rise of shale oil, and the ability to successfully cope with them. The company was at the forefront of reform in the industry, driving privatization in the 1990s and technological innovation pertaining to shale oil in the 2000s and 2010s. It responded flexibly to the challenges posed by oil price volatility and sanctions. 
While LUKOIL enjoys close ties with the Russian authorities and appears committed to paying taxes, the company has also been keen to explore international opportunities through partnerships with foreign companies as well as to develop upstream and downstream business abroad both in the post-Soviet states and further afield. Sanctions have hampered its ability to reach its full potential in foreign markets. Nonetheless, it has managed to develop important foreign oil and gas fields and has established extensive fuel distribution networks. LUKOIL also prides itself on its support for technological innovation in several areas, including hard-to-recover reserves and renewable energy.

The company has paid some attention to climate change and GHG emissions by measuring its climate change impact, the utilization of associated gas rather than flaring it, and developing new climate change mitigation technologies.

LUKOIL seeks to maintain its reputation as a good corporate citizen who engages in various social investment activities across the areas where it operates. In Russia, this is done largely via agreements negotiated with local authorities. Successive sustainability reports indicate LUKOIL's growing awareness of the need to strengthen its communication with the general public concerning environmental protection and the well-being of local communities in its regions of operations. The company has, however, faced challenges in maintaining its social licence to operate in areas particularly affected by oil spills, notably the Komi Republic where local communities actively protested and succeeded in halting LUKOIL's operations - at least for a while. This event may have also convinced the company's management to bring community concerns to the fore in its public relations announcements.

Transparency is important to LUKOIL, and it has committed itself to several international and domestic initiatives requiring transparency and reporting. It has performed relatively well in ranking exercises that have assessed the transparency and sustainability performance of oil companies. More importantly, these indicators indicate improvement over time. 


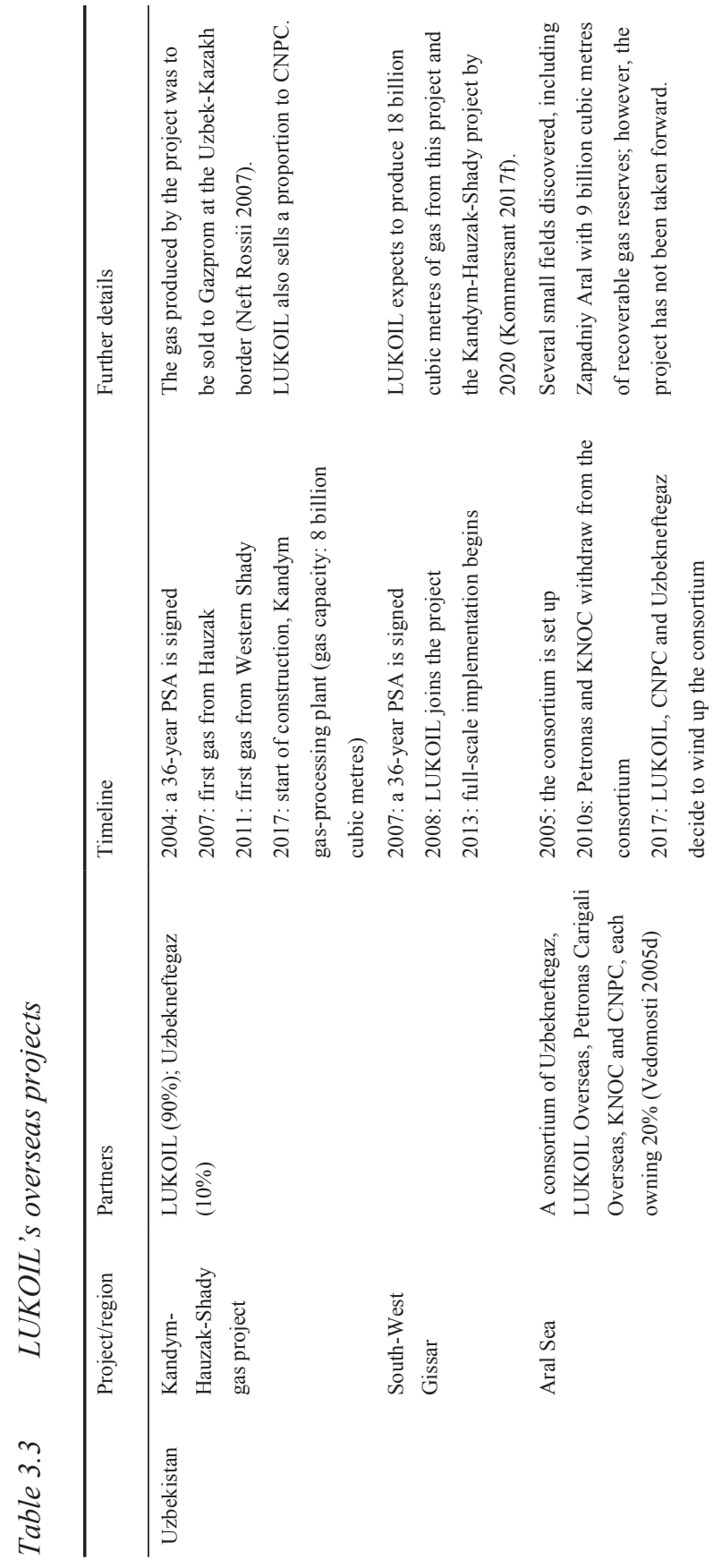




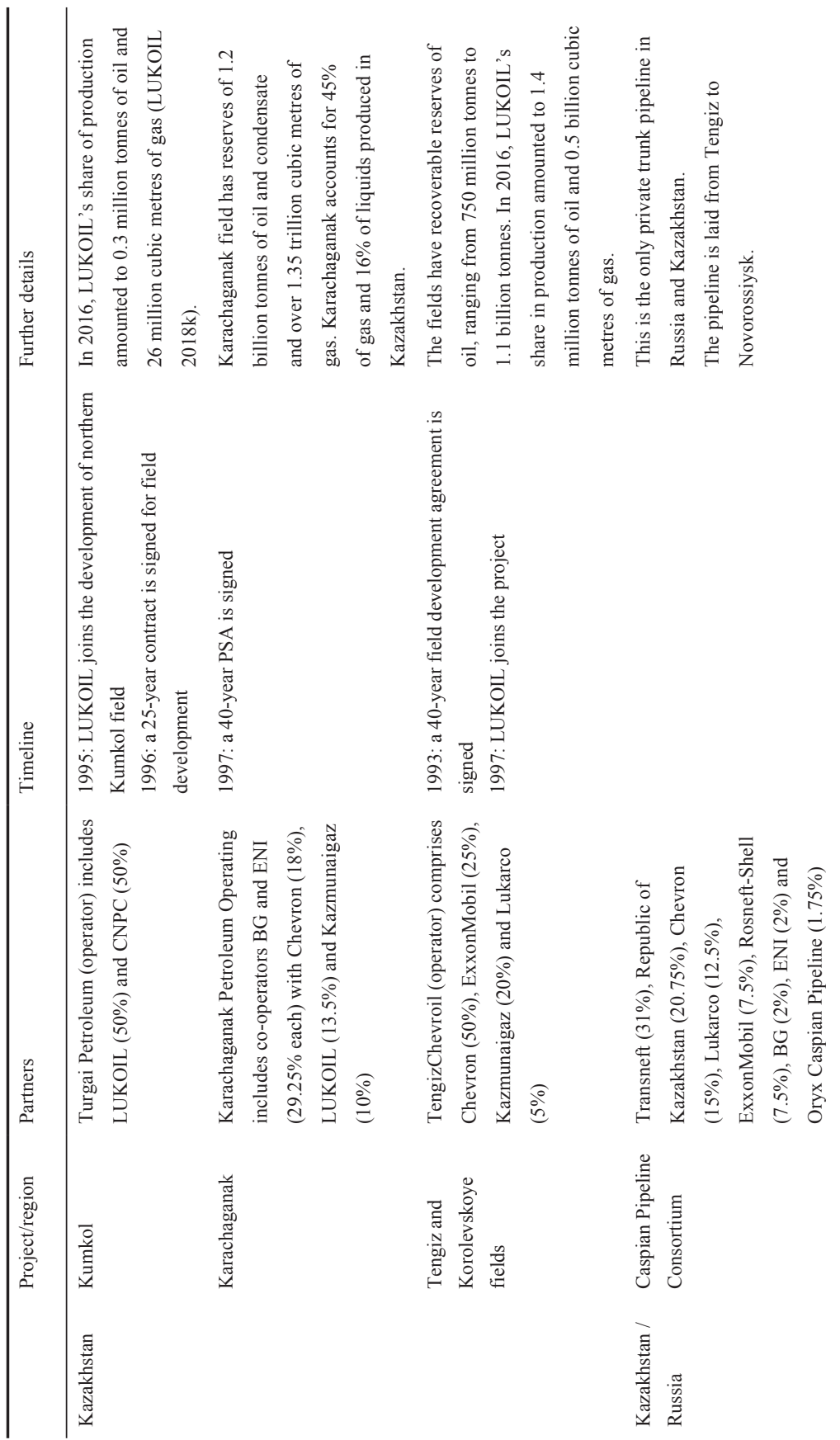




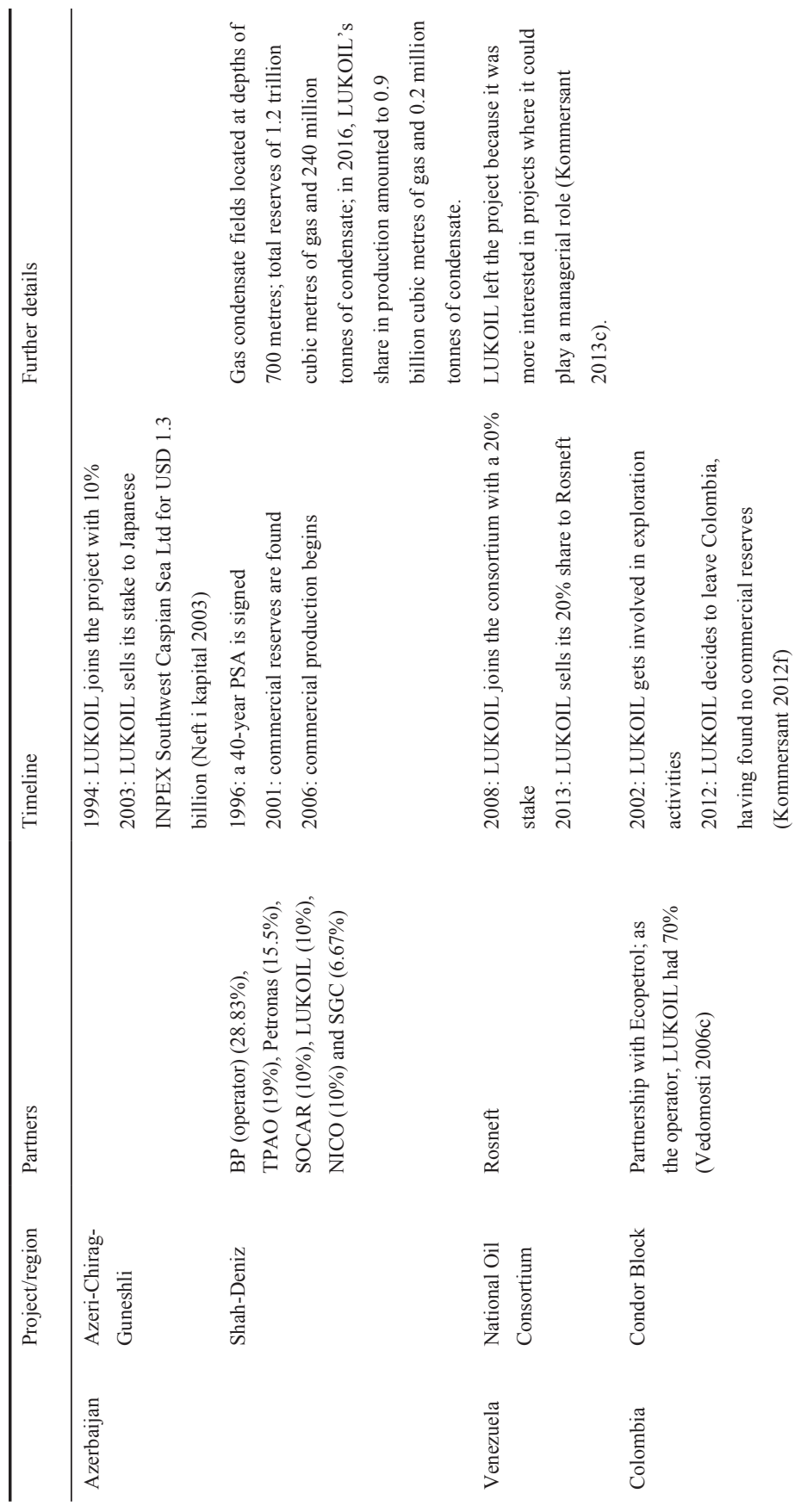




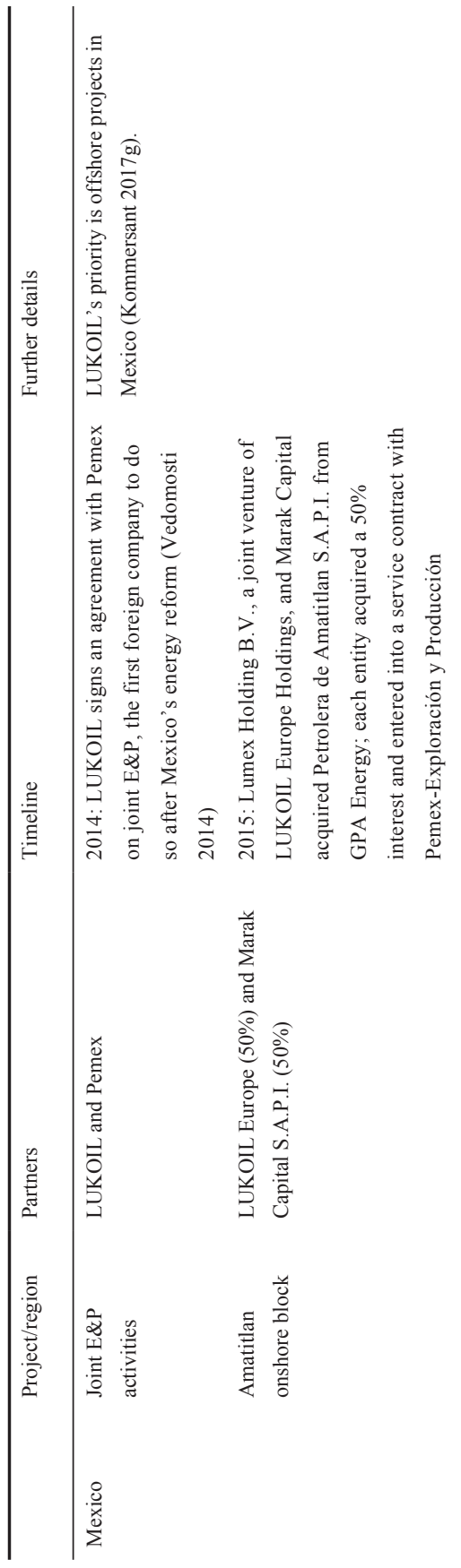




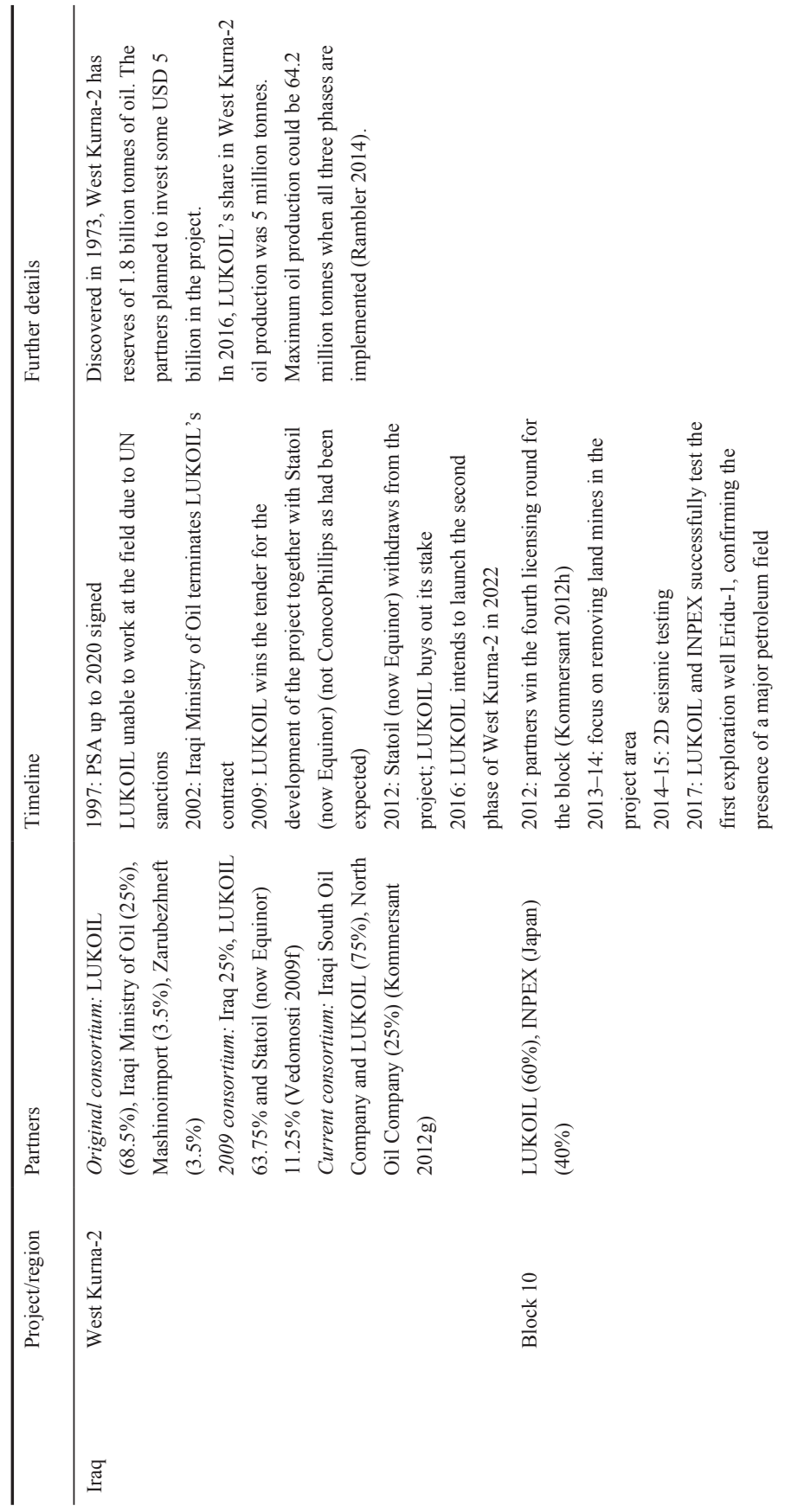




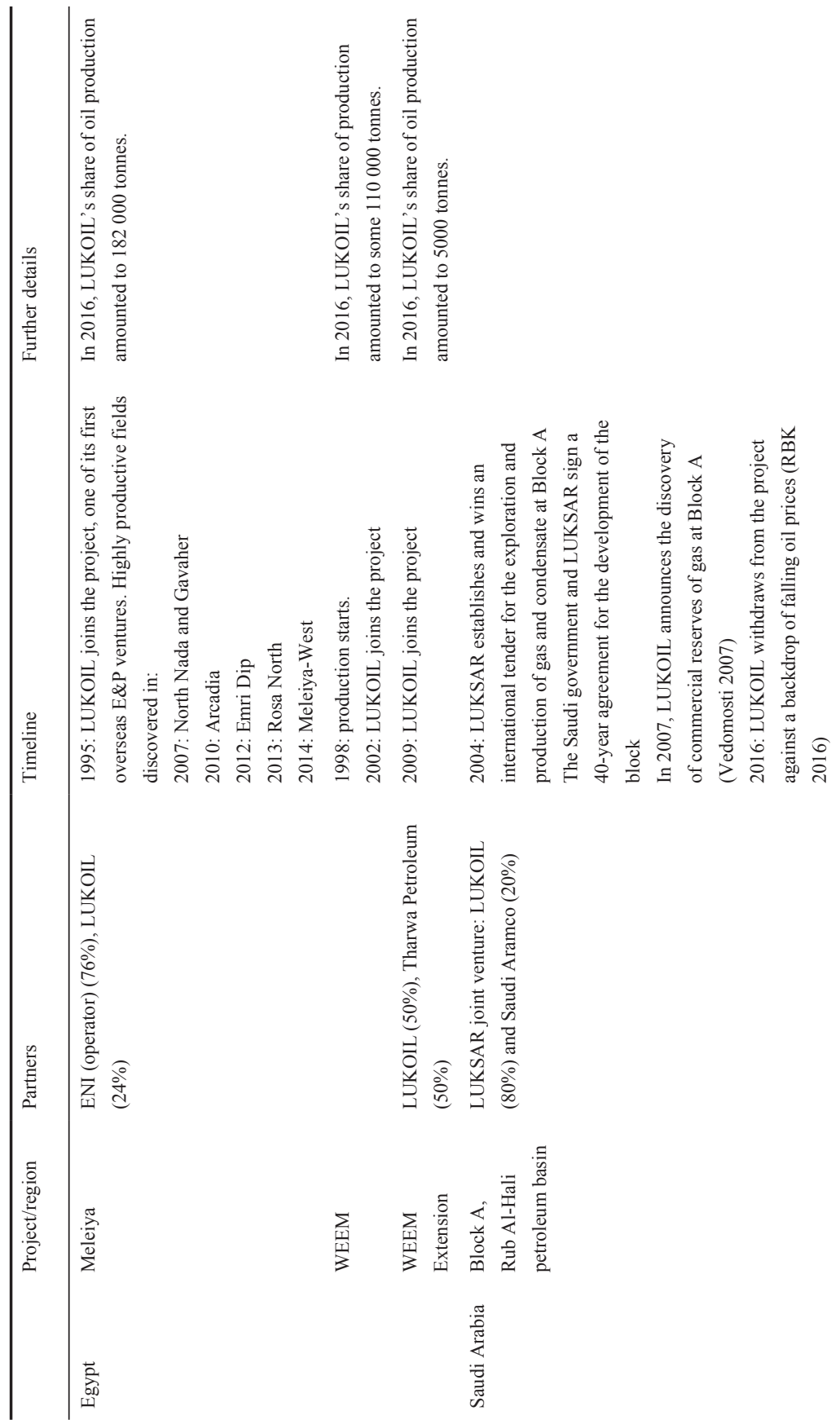




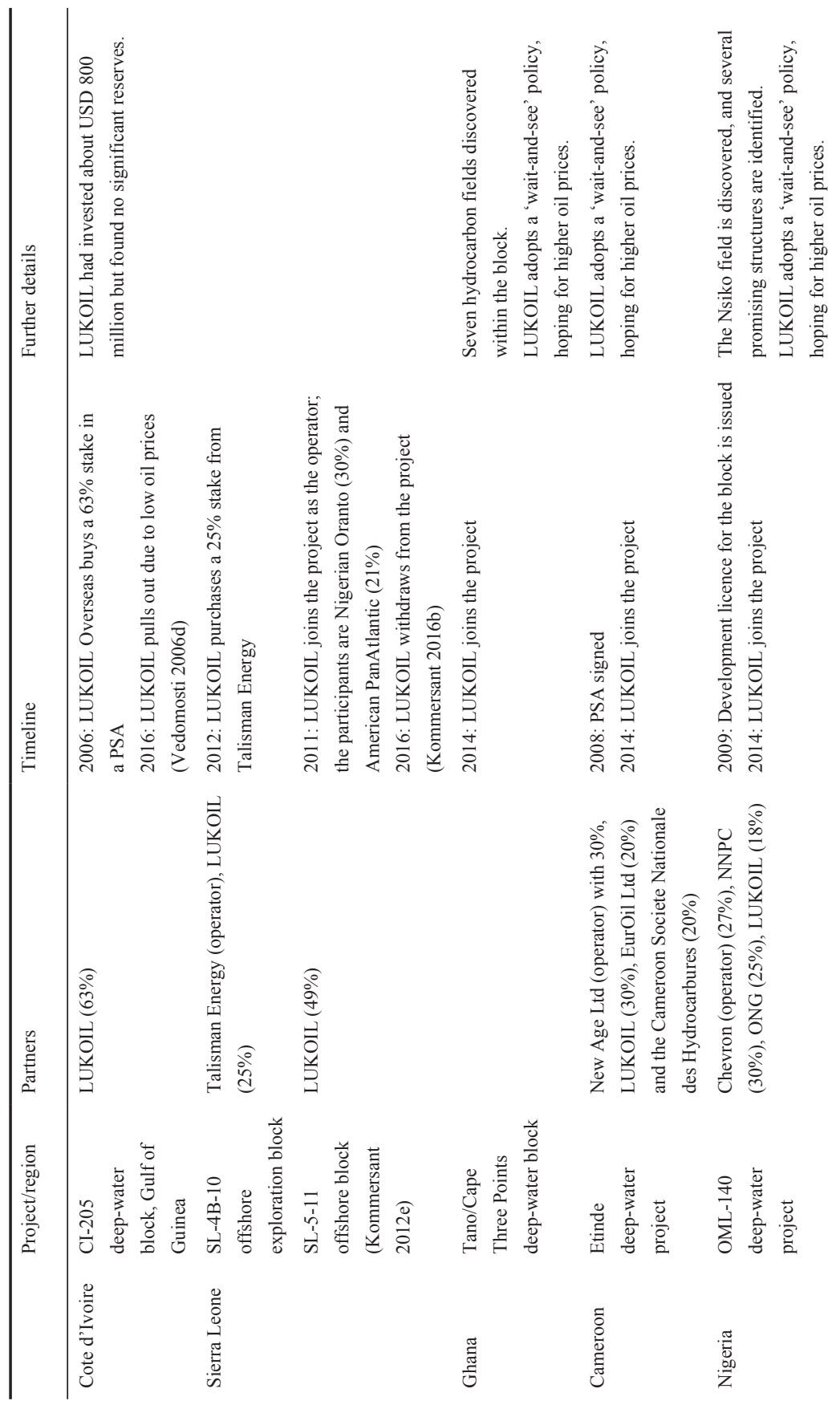




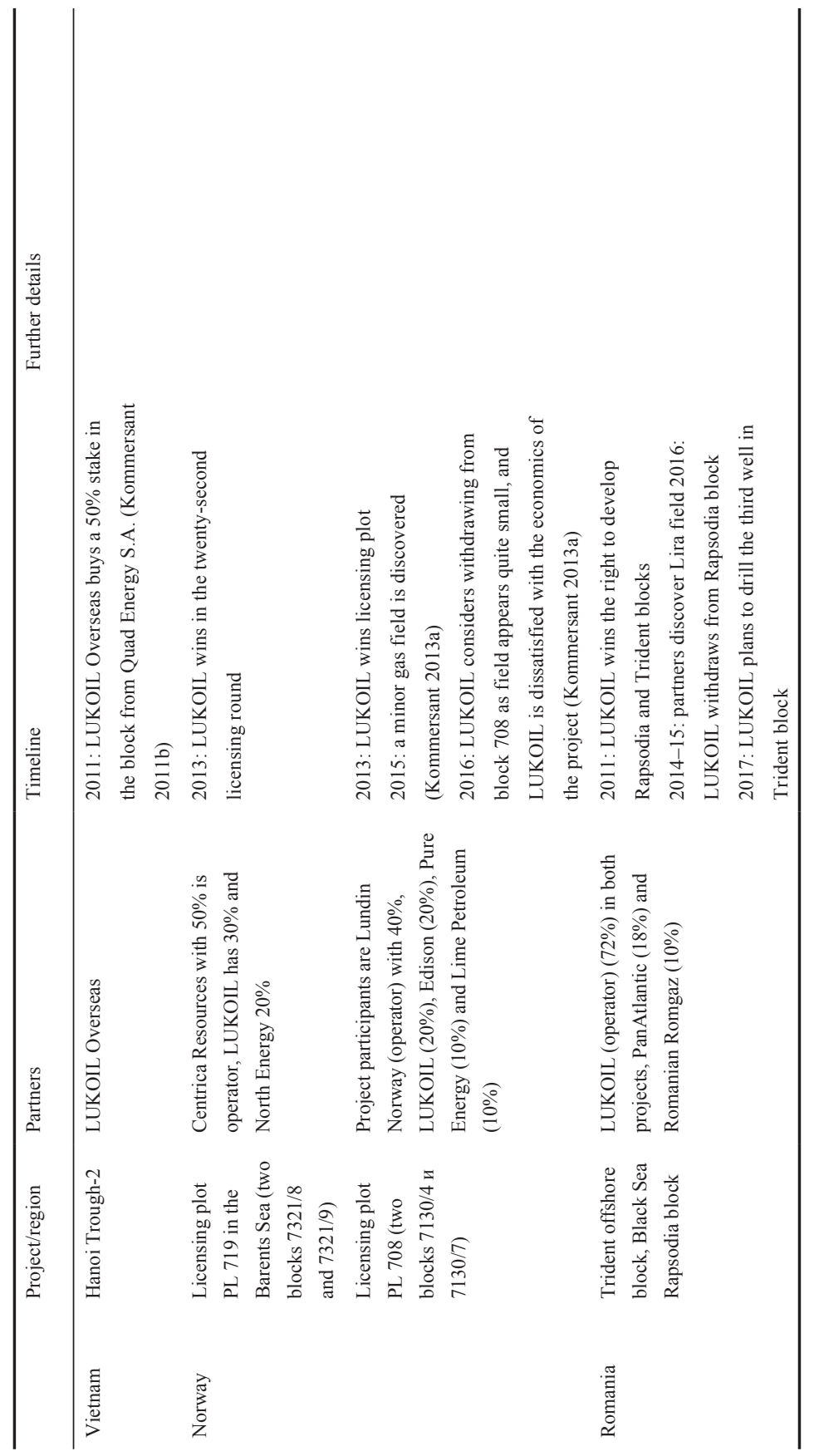




\section{NOTE}

1. The Imilorsko-Istochniy licensing area includes Imilorskoye, Zapadno-Imilorskoye and Istochnoye fields and is located in the Surgut region of Khanty-Mansi Autonomous District. In 2014, LUKOIL launched Imilorskoye field, one of the largest new fields of Western Siberia.

\section{REFERENCES}

Alekperov, V. (2009), 'Net fundamentalhykh prichin dlya tsen na neft nizhe $\$ 40 \mathrm{i}$ vyshe \$70', Vedomosti, 5 June.

Alekperov, V. (2011), Neft Rossii: Proshloye, Nastoyaschee i Buduschee, Moscow: Kreativnaya Ekonomika.

EITI (2018a), 'The global standard for the good governance of oil, gas and mineral resources', accessed 12 October 2018 at https://eiti.org/.

EITI (2018b), 'Companies', accessed 12 October 2018 at https://eiti.org/supporters/ companies.

Energetika i Promyshlennost Rossii (2008), 'LUKOIL popal v italiyanskuyu pererabotku', accessed 12 October 2018 at https://www.eprussia.ru/pressa/articles/ 11218.htm.

Energyland (2008), 'LUKOIL vybral Rossiyu', accessed 12 October 2018 at http:// www.energyland.info/analitic-show-5229.

EURACTIV (2018), 'LUKOIL CEO: Russian oil business prospers in EU', accessed 12 October 2018 at https://www.euractiv.com/section/energy/interview/lukoil-ceo -russian-oil-business-prospers-in-eu/.

Forbes (2009), 'Ostorozhno LUKOIL', accessed 12 October 2018 at http://www .Forbes.ru/ekonomika/kompanii/17235-ostorozhno-C2\%ABlukoil\%C2\%BB.

Gaiduk, I. and O. Lukin (2006), 'LUKOIL moving into Europe', accessed 12 October 2018 at www.wtexecutive.com/cms/content.jsp?id=com.tms.cms.article.article_rpi insight_LUKOILEurope.

Global Reporting (2019), 'About', accessed 22 January 2019 at https://www .globalreporting.org/Pages/default.aspx.

Gorst, I. (2007), 'LUKOIL: Russia's largest oil company' written for 'The changing role of national oil companies in international energy market', James A. Baker III Institute for Public Policy Report.

Gorst, I. and N. Poussenkova (1998), 'Petroleum ambassadors of Russia' written for 'Unlocking the assets: Energy and the future of Central Asia and the Caucasus', James A. Baker III Institute for Public Policy Report.

Greenpeace (2014), 'Komi-izhemtcy obyavili LUKOIL personoy non-grata', accessed 14 October 2018 at http://www.greenpeace.org/russia/ru/news/blogs/green-planet/-/ blog/48716/.

GRI (2018), 'GRI Standards', accessed 12 October 2018 at https://www.globalreporting .org/Pages/default.aspx.

Hudson, J. (1996), Russian Oil, Vertically Integrated Companies, Volume 3 of Report on Russian Oil, London: Salomon Brothers.

Kelman, I., J.S. Loe, E.W. Rowe, E. Wilson, N. Poussenkova, E. Nikitina and D.B. Fjærtoft (2016), 'Local perceptions of corporate social responsibility for Arctic petroleum in the Barents Region', Arctic Review, 7 (2), 152-78. 
Khrennikov, I. (2007), 'LUKOIL: Pro zapas', Forbes, accessed 11 October 2018 at http://www.Forbes.ru/Forbes/issue/2007-06/12377-lukoil-pro-zapas.

Kommersant (1996), 'Sobraniye aktsionerov LUKOYLa: Neftyanaya kompaniya vpolne dovolna soboy', accessed 22 January 2019 at https://www.kommersant.ru/ doc/134111.

Kommersant (2011a), 'LUKOIL otbil litsenziyu', accessed 12 October 2018 at https:// www.kommersant.ru/doc/1689728.

Kommersant (2011b), 'LUKOIL proburit Vietnamskiy shelf', accessed 14 October 2018 at https://www.kommersant.ru/doc/1633888.

Kommersant (2012a), 'LUKOIL rasplatilsya za oshibki geologov', accessed 12 October 2018 at https://www.kommersant.ru/doc/1884165.

Kommersant (2012b), 'Minprirody vozvraschayet Trebsa i Titova', accessed 12 October 2018 at https://www.kommersant.ru/doc/1901026.

Kommersant (2012c), 'LUKOIL zabral u Rossii samoye dorogoye', accessed 12 October 2018 at https://www.kommersant.ru/doc/2098523.

Kommersant (2012d), 'LUKOIL sokraschayet serbskuyu roznitsu', accessed 12 October 2018 at https://www.kommersant.ru/doc/2042339.

Kommersant (2012e), 'LUKOIL ukrepil Afrikanskiy blok', accessed 12 October 2018 at https://www.kommersant.ru/doc/2062229.

Kommersant (2012f), 'LUKOIL vypustil Kondora', accessed 14 October 2018 at https://www.kommersant.ru/doc/2088810.

Kommersant (2012g), 'LUKOIL ostaetsya v Irake odin', accessed 14 October 2018 at https://www.kommersant.ru/doc/1864335.

Kommersant (2012h), 'Neftyanoye peremiriye', accessed 14 October 2018 at https:// www.kommersant.ru/doc/2041743.

Kommersant (2013a), 'Rossiya poluchila dolyu v Norvegii', accessed 12 October 2018 at https://www.kommersant.ru/doc/2210881https://www.kommersant.ru/doc/ 2210881.

Kommersant (2013b), 'LUKOIL dunul v Bolgariyu', accessed 14 October 2018 at https://www.kommersant.ru/gallery/2260031.

Kommersant (2013c), 'Venezuelu ostavyat goskompaniyam', accessed 14 October 2018 at http://enewz.ru/news/2001-venesuelu-ostavyat-goskompaniyam.html.

Kommersant (2016a), 'LUKOIL zasomnevalsya v Norvegii', accessed 12 October 2018 at https://www.kommersant.ru/doc/3150349.

Kommersant (2016b), 'LUKOIL razocharovalsya v Afrike', accessed 14 October 2018 at https://www.kommersant.ru/doc/2895093.

Kommersant (2017a), 'Kompaniy v Rossii vse menshe i menshe, i vse khuzhe i khuzhe aktivy, kotorye u nikh ostayutsya', accessed 11 October 2018 at https://www .kommersant.ru /doc/3508459.

Kommersant (2017b), 'LUKOIL nashel mesto na shelfe Rumynii', accessed 12 October 2018 at https://www.kommersant.ru/doc/3344753.

Kommersant (2017c), 'LUKOIL zatailsya na shelfe Afriki', accessed 12 October 2018 at https:/www.kommersant.ru/doc/3325601.

Kommersant (2017d), 'LUKOIL distantsiruetsya ot svoego treidera', accessed 14 October 2018 at https://www.kommersant.ru/doc/3397679.

Kommersant (2017e), 'Seichas suschestvuet potentsialnaya ugroza, svyazannaya s novym paketom sanktsiy', accessed 14 October 2018 at https://www.kommersant $. \mathrm{ru} / \mathrm{doc} / 3416333$.

Kommersant (2017f), 'LUKOIL vybralsya iz Arala', accessed 14 October 2018 at https://www.kommersant.ru/doc/3219937. 
Kommersant (2017g), 'LUKOIL nashel partnera v Meksike', accessed 14 October 2018 at https://www.kommersant.ru/doc/3188639.

London Stock Exchange (2018), 'Rules and regulations', accessed 12 October 2018 at https://www.londonstockexchange.com/companies-and-advisors/main-market/ rules/regulations.htm.

LUKOIL (2012), Sustainability Report 2011-2012, accessed 17 April 2019 at http:// www.lukoil.com/InvestorAndShareholderCenter/ReportsAndPresentations/ SustainabilityReport/SustainabilityReportArchive2003-2008.

LUKOIL (2016a), Annual Report 2016, accessed 12 October 2018 at http://www.lukoil .com/InvestorAndShareholderCenter/ReportsAndPresentations/FinancialReports.

LUKOIL (2016b), Sustainable Development Report, 2015-2016, accessed 12 October 2018 at http://www.lukoil.com/InvestorAndShareholderCenter/ ReportsAndPresentations/SustainabilityReport.

LUKOIL (2017), Making Opportunities Reality: LUKOIL Group Sustainability Report 2017, accessed 21 April 2020 at https://csr2017.lukoil.com/download/full-reports/ csr_en_annual-report_pages.pdf.

LUKOIL (2018a), 'LUKOIL's assets around the world \& LUKOIL's assets in Russia', accessed 11 October 2018 at http://www.lukoil.ru/Business.

LUKOIL (2018b), 'Oil refining', accessed 11 October 2018 at http://www.lukoil.ru/ Business/Downstream/OilRefining.

LUKOIL (2018c), 'Corporate profile', accessed 11 October 2018 at http://www.lukoil .Ru/Company/Corporateprofile.

LUKOIL (2018d), 'Growth projects', accessed 12 October 2018 at http://www.lukoil .ru/Business/Upstream/KeyProjects.

LUKOIL (2018e), 'Gas processing', accessed 12 October 2018 at http://www.lukoil.ru/ Business/Downstream/GasProcessing.

LUKOIL (2018f), 'Petrochemicals', accessed 12 October 2018 at http://www.lukoil.ru/ Business/Downstream/Petrochemicals.

LUKOIL (2018g), 'History. 2000', accessed 12 October 2018 at http://www.lukoil.ru/ Company/history/History2000.

LUKOIL (2018h), 'LUKOIL charity fund', accessed 12 October 2018 at http:// www.lukoil.com/Responsibility/SocialInvestment/SocialInitiatives/

LUKOILCharityFund.

LUKOIL (2018i), 'Osnovnyye tendentcii razvitiya mirovogo rynka nefti do 2030 goda', accessed 14 October 2018 at http:/www.lukoil.ru/FileSystem/PressCenter/ 84523.pdf.

LUKOIL (2018j), 'Sbyt', accessed 14 October 2018 at http://www.lukoil.ru/ InvestorAndShareholderCenter/IrTool/InteractiveAnalysis/interactive-analysis -neww12?wid=widasul-rUAlkSyqp12NMVIdg.

LUKOIL (2018k), 'Zarubezhnyye proekty', accessed 14 October 2018 at http://www .lukoil.ru/Business/Upstream/Overseas.

LUKOIL (20181), Sustainable Development Report, 2018, accessed 3 December 2019 at http://www.lukoil.com/InvestorAndShareholderCenter/ReportsAndPresentations/ Sus tainabilityReport.

LUKOIL (2019a), 'Social Code of PJSC LUKOIL', accessed 22 January 2019 at http:// www.lukoil.com/Responsibility/SocialPartnership/SocialCodeofPJSCLUKOIL/ socialcodehtmlversion.

LUKOIL (2019b), 'Spravochnik Analitika', accessed 3 December 2019 at http://www .extraowa.lukoil.com. 
Neft i kapital (2002), 'LUKOIL okonchatelno utratil vozmozhnost uchastvovat v konkurse po Gdanskomu NPZ', accessed 12 October 2018 at https:/oilcapital.ru/ news/markets/21-10-2002/lukoyl-okonchatelno-utratil-vozmozhnost-uchastvovat-v -konkurse-po-gdanskomu-npz.

Neft i kapital (2003), 'LUKOIL zavershayet prodazhu svoey doli v proekte Azeri-Chirag-Gyuneshli INPEKSu', accessed 12 October 2018 at https://oilcapital .ru/news/markets/28-04-2003/lukoyl-zavershaet-prodazhu-svoey-doli-v-proekte -azeri-chirag-gyuneshli-inpeksu.

Neft Rossii (2007), 'LUKOIL sbezhal ot Gazproma', accessed 14 October 2018 at http://www.oilru.com/news/59489/.

Neft Rossii (2016), 'Period “odin na odin" s gosudarstvom my uzhe prohodili', accessed 12 October 2018 at http://www.oilru.com/news/533114/.

Neftegaz.ru (2000), 'O finansovoy otchetnosti gruppy LUKOYL', accessed 22 January 2019 at https://neftegaz.ru/news/view/1321-O-FINANSOVOY-OTChETNOSTI -GRUPPY-LUKOYL.

Neftegaz.ru (2007), 'LUKOIL - v prezhnih granitsah', accessed 12 October 2018 at https://neftegaz.ru/press/view/3387.

Neftegaz.ru (2010), 'Moya missiya esche ne zakonchena', accessed 14 October 2018 at https://neftegaz.ru/news/view/96635-Alekperov-missiya-ne-zakonchena.

Neftegaz.ru (2017), 'RITEK prodoljayet vnyedryat tekhnologiyu termogazovogo vozdeystviya na plasty Bazhenovskoy svity v HMAO', accessed 14 October 2018 at https://neftegaz.ru/news/view/159803-RITEK-prodolzhaet-vnedryat-tehnologiyu -termogazovogo-vozdeystviya-na-plasty-bazhenovskoy-svity-v-HMAO.

Neftrossii.ru (2014), 'Vagit Alekperov nagrazhdon ordenom "za zaslugi pered otechestvom" ii stepeni', accessed 22 January 2019 at https://neftrossii.ru/content/vagit -alekperov-nagrazhdyon-ordenom-za-zaslugi-pered-otechestvom-ii-stepeni.

Newsru.com (2002), 'LUKOIL obyavil o prodazhe svoyey doli v Azerbaidzhanskom proekte', accessed 12 October 2018 at https://www.newsru.com/finance/18nov2002/ lukoil3.html.

Oilcareer.ru (2009), 'LUKOIL sokrashchayet personal?', accessed 14 October 2018 at http://www.oilcareer.ru/news/lukoil_sokrashhaet_personal/2009-10-28-162.

Oilgas.com (2017), 'RITEK pristupil k ispytaniyam tekhnologii termogazovogo vozdeystviya na plasty bazhenovskoy svity', accessed 14 October 2018 at http:// oilgascom.com $/ \% \mathrm{E} 2 \% 80 \% \mathrm{~A} 2-\% \mathrm{E} 2 \% 80 \% 8$ Britek-pristupil-k-ispytaniyam -texnologii-termogazovogo-vozdejstviya-na-plasty-bazhenovskoj-svity/.

Poussenkova, N. (2010), 'Dvadtsat let, kotoryye potryasli mir', Istoryya Novoy Rossyy, accessed 12 October 2018 at http://www.ru-90.ru/node/1319.

Rambler (2014), 'Alekperov: LUKOIL verit v stabilnyy Irak', accessed 14 October 2018 at https://finance.rambler.ru/economics/25597462-alekperov-lukoyl-verit-v -stabilnyy-irak/.

RBK (2016), 'LUKOIL zayavil ob uhode iz Saudovskoy Aravii', accessed 14 October 2018 at https://www.rbc.ru/rbcfreenews/5762802a9a794724eff78999.

Reuters (2014), 'Russia's LUKOIL to drill for tight gas in Saudi desert', accessed 14 October 2018 at https://www.reuters.com/article/saudi-lukoil-gas/russias-lukoil-to -drill-for-tight-gas-in-saudi-desert-idUSL6N0O034G20140515.

Ria Novosti (2002), 'LUKOIL vykhodit iz proyekta Azeri-Chirag-Gyuneshli', accessed 12 October 2018 at https://ria.ru/economy/20021220/286344.html.

Russian Union of Industrialists and Entrepreneurs (2019), 'Social Charter of the Russian business’, accessed 22 January 2019 at http://eng.rspp.ru/simplepage/860. 
Sberbank CIB (2017), 'Russian oil and gas tomorrow is a distant memory', accessed 14 October 2018 at http://neftianka.ru/wp-content/uploads/2017/11/2 5467772892869558529.pdf.pdf.

TASS (2015), 'Total pokroyet LUKOILu zatraty na razrabotku Bazhenovskoy svity pri vozvrashenii v proyekt', accessed 14 October 2018 at https://tass.ru/tek/2555532.

The Barrel (2015), 'Private companies struggle for Russian offshore opportunities: Regulation and environment', accessed 12 October 2018 at http://blogs.platts.com/ 2015/04/13/private-companies-offshore-russia-oil/.

Transparency International (2011), 'Promoting revenue transparency: 2011 report on oil and gas companies', accessed 12 October 2018 at https://www.transparency.org/ whatwedo/publication/promoting_revenue_transparency_2011_report_on_oil_and gas_companies.

United Nations Global Compact (2019), 'Russia', accessed 22 January 2019 at https:// www.unglobalcompact.org/engage-locally/europe/russia.

Vedomosti (2005a), 'LUKOIL postavit benzin v SShA', accessed 12 October 2018 at https://neftegaz.ru/press/view/1836.

Vedomosti (2005b), 'LUKOIL potratil 2 milliarda', accessed 22 January 2019 at https://neftegaz.ru/press/view/1843.

Vedomosti (2005c), 'Alekperov dogovorilsya s Nazarbayevym', accessed 12 October 2018 at https://www.pressreader.com/russia/vedomosti/20051024/ 281745559782989.

Vedomosti (2005d), 'LUKOIL idyet v Uzbekistan', accessed 22 January 2019 at https://www.vedomosti.ru/newspaper/articles/2005/09/09/lukojl-idet-v-uzbekistan.

Vedomosti (2006a), 'LUKOIL stanet partnerom Petrol', accessed 22 January 2019 at https://www.eprussia.ru/pressa/articles/3866.htm.

Vedomosti (2006b), 'U kitaitsev bolshe vozmozhnostei, chem u nas', accessed 12 October 2018 at https://www.gubkin.ru/news/detail_ajax.php?ID=1633\&sphrase_id $=4517116 \#$ Toc 144772934 .

Vedomosti (2006c), 'LUKOILu ponravilos v Kolumbii', accessed 22 January 2019 at https://www.vedomosti.ru/newspaper/articles/2006/04/11/lukojlu-ponravilos-v -kolumbii.

Vedomosti (2006d), 'LUKOIL dobralsya do zapadnoi Afriki', accessed 14 October 2018 at https://www.pressreader.com/russia/vedomosti/20060717/textview.

Vedomosti (2007), 'Gaz iz serdtsa OPEC', accessed 14 October 2018 at https://www .pressreader.com/russia/vedomosti/20070213/281878703906240.

Vedomosti (2008a), 'Ne nashli ni nefti, ni gaza', accessed 12 October 2018 at https:// www.vedomosti.ru/library/articles/2008/09/03/riskovye-francuzy.

Vedomosti (2008b), 'Gotovy k dobyche', accessed 22 January 2019 at https://www .eprussia.ru/pressa/articles/11185.htm.

Vedomosti (2008c), 'Don Alekperov', accessed 12 October 2018 at http://www .zagolovki.ru/article/25Jun2008/don.

Vedomosti (2009a), 'Opyat sukho', accessed 22 January 2019 at https://www.vedomosti .ru/newspaper/articles/2009/01/13/opyat-suho.

Vedomosti (2009b), 'BP ushla iz KTK', accessed 12 October 2018 at https://www .vedomosti.ru/newspaper/articles/2009/12/14/vr-ushla-iz-ktk.

Vedomosti (2009c), 'Ot Sitsilii do Gollandii', accessed 12 October 2018 at https://www .pressreader.com/russia/vedomosti/20090622/281646776119197.

Vedomosti (2009d), 'Oboshel Exxon', accessed 14 October 2018 at http://ukrrudprom .ua/digest/Oboshel_Exxon.html?print. 
Vedomosti (2009e), 'Skolko stoit neft?', accessed 14 October 2018 at https://www .pressreader.com/russia/vedomosti/20090605/281676840879096.

Vedomosti (2009f), 'LUKOIL vozvraschayetsya v Iraq', accessed 18 February 2019 at https://www.vedomosti.ru/business/articles/2009/12/14/lukojl-vozvraschaetsya-v - irak $\% 20$.

Vedomosti (2010a), 'Patrioty iz LUKOILa', accessed 12 October 2018 at http://www .energyland.info/analitic-show-51848.

Vedomosti (2010b), 'Postoronnim vhod zapreschen', accessed 12 October 2018 at http://stocks.investfunds.ru/news/11114/.

Vedomosti (2010c), 'Otstupniye dlya LUKOILa', accessed 12 October 2018 at https:// www.pressreader.com/russia/vedomosti/20100823/281805690237144.

Vedomosti (2011), 'Amerike ne zalivat', accessed 12 October 2018 at http://www.case -hr.com/novosti-rinka/35350.html.

Vedomosti (2012a), 'Rosnedra prepodnesli neftyannikam "vnezapniy syurpriz", accessed 12 October 2018 at https://www.vedomosti.ru/business/articles/2012/05/ $22 /$ partner stvo vo imya nefti.

Vedomosti (2012b), 'LUKOIL peredumal idti na shelf s Rosneftiyu', accessed 12 October 2018 at https://www.vedomosti.ru/business/articles/2012/04/27/lukojl peredumal.

Vedomosti (2012c), 'LUKOIL zapravit Benilux', accessed 14 October 2018 at https:// www.vedomosti.ru/business/articles/2012/04/13/lukojl_zapravit_benilyuks.

Vedomosti (2013a), 'Razve ya pohozh na cheloveka, kotoryi chto-to prodaet?', accessed 21 April 2020 at http://enkorr.com.ua/a/interview/Vagit_Alekperov_Razve ya_pohozh_na_cheloveka_kotoriy_chto-to prodaet/209806.

Vedomosti $(20 \overline{1} 3 \mathrm{~b})$, 'LUKOIL vysaditsya na Sitsilii', accessed 12 October 2018 at http://stocks.investfunds.ru/news/49591/.

Vedomosti (2013c), 'Avoski i valenki obyedinyayutsya', accessed 14 October 2018 at https://www.pressreader.com/russia/vedomosti/20131011/textview.

Vedomosti (2014), 'LUKOIL idet v Meksiku', accessed 14 October 2018 at http:// stocks.investfunds.ru/news/55193/.

Vedomosti (2016a), 'Dohodnoye mesto LUKOILa', accessed 12 October 2018 at https://www.vedomosti.ru/business/articles/2016/12/16/669889-dohodnim -regionom-lukoila.

Vedomosti (2016b), 'Lishniy benzin', accessed 22 January 2019 at https://www .vedomosti.ru/business/articles/2016/02/08/627725-lukoil-zapravok-baltii.

Vestifinance.ru (2014), 'LUKOIL i Total sozdali SP po Bazhenovskoy svite', accessed 14 October 2018 at https://www.vestifinance.ru/articles/43146. 